\title{
La inconstitucionalidad por omisión legislativa: a escena la omisión legislativa convencional
}

\section{The unconstitutional legislative inaction: a conventional scene legislative omission}

\author{
Juan Marcelino González Garcete \\ Abogado, máster en Criminología Forense; doctor en Derecho; doctorado (en curso) \\ en Ciencias Politicas y en Ciencias de la Educación; profesor de Derecho Constitucional y \\ Derecho Administrativo de la Universidad Nacional de Asunción, Paraguay. \\ Correo electrónico: jmgonzalez704@gmail.com
}

Jaime Alfonso Cubides Cárdenas

Abogado, especialista en Derecho Público por la Universidad Autónoma de Colombia (Col.); especialista y magister en Docencia e Investigación con énfasis en Ciencias Jurídicas y maestría (en curso) en Derecho Administrativo por la Universidad Sergio Arboleda (Col.); doctorado (en curso) en Derecho Universidad de Buenos Aires. Docente investigador Universidad Católica de Colombia (Col.).

Correo electrónico: jacubides@ucatolica.edu.co

María Paula Santofimio Díaz

Investigadora auxiliar, vinculada al grupo de investigación: Persona, Instituciones y Exigencias de Justicia de la Universidad Católica de Colombia (Col.).

Correo electrónico: mpsantofimio83@gmail.com

\begin{abstract}
Resumen
El presente texto es resultado de un estudio investigativo de la omisión legislativa, su propósito es analizar esta figura a partir de diversos ángulos, entendiendo que la construcción de un sistema jurídico sea una respuesta eficaz a la compleja realidad de nuestro tiempo, la cual se nos muestra como una ineludible exigencia de la lógica del derecho. Esta necesidad obliga a plantear nuevas figuras donde se manifieste la técnica jurídica. Una de ellas es la inconstitucionalidad por omisión, la cual despierta en nosotros un elevadísimo interés, pese a que la doctrina, en general, no le ha dedicado excesiva atención. A su vez, se analizará el control de convencionalidad y se propondrá el concepto de "omisión legislativa convencional", ejemplificándolo con varias sentencias de la Corte IDH.
\end{abstract}

Palabras clave: Omisión legislativa, inconstitucionalidad, control de convencionalidad, sistema jurídico, Convención Americana de Derechos Humanos, Corte Interamericana de Derechos Humanos, derechos humanos.

\begin{abstract}
This paper is the result of a research analysis of the legislative omission, its purpose is analyze this concept from different perspectives, knowing that the construction of a legal system that provides effective response to the complex reality of our time, appears as an requirement of the logic of law. This need, compel us to create new resources that reflect the legal technique. One is the unconstitutional omission, which is so interesting for us, but isn't developed by the doctrine. Furthermore, it analyzes the conventionality control and purpose the concept of conventional legislative omission, showing different judgements of the Interamerican Court of Human Rights.
\end{abstract}

Keywords: Legislative omission, unconstitutional omission, conventionality control, American Convention on Human Rights, Interamerican Court of Human Rights, human rights.

Recibido: 05 de mayo de 2015; Aprobado: 15 de agosto de 2015 


\section{Résumé}

Ce texte est le résultat d'une analyse de recherche de l'omission législative, son but est d'analyser ce chiffre à partir de différents angles, comprendre que la construction d'un système juridique est une réponse efficace à la réalité complexe de notre temps, que nous Il est présenté comme une condition essentielle de la logique de la loi. Cette nécessité oblige à soulever de nouvelles figures où la technique juridique se révèle. L'un est l'inconstitutionnalité par omission, qui éveille en nous un intérêt très élevé, bien que la doctrine, en général, n'a pas consacré beaucoup d'attention. À son tour, le contrôle de conformité sera analysée et le concept de «l'omission législative classique”, ce qui illustre avec plusieurs arrêts de la Cour interaméricaine est proposé.

Mots-clés: Omission législative, constitutionnelle, contrôle de conventionnalité, système juridique, la Convention américaine relative aux droits de l'homme, Cour interaméricaine des droits de l'homme, les droits de l'homme. 


\title{
La inconstitucionalidad por omisión legislativa: a escena la omisión legislativa convencional ${ }^{*}$
}

\author{
Juan Marcelino González Garcete \\ Jaime Alfonso Cubides Cárdenas \\ María Paula Santofimio Díaz
}

\section{INTRODUCCIÓN: NOCIÓN DE OMISIÓN INCONSTITUCIONAL}

El presente texto pretende responder diversos interrogantes relacionados con el manejo de la omisión de inconstitucionalidad en diferentes países latinoamericanos: ¿Qué es una inconstitucionalidad por omisión? ¿Cuáles son los órganos del Estado responsables de evitarla y cuáles de subsanarla? ¿Qué nos dicen la doctrina y los ordenamientos jurídicos de otros países acerca de este instituto? ¿Qué tipos de derechos sufren mayor menoscabo a través de estas omisiones? ¿Son esencialmente diferentes los derechos sociales, económicos y culturales, de los derechos civiles y políticos? ¿Qué tipo de jueces son necesarios para aplicar la inconstitucionalidad por omisión? ${ }^{1}$

Sin ánimo de agotar todo ese caudal de preguntas en estas breves líneas, y a los simples fines de despertar interés en un instituto poco visible en nuestro ordenamiento, se expondrán aquí tan solo algunos conceptos relativos a la inconstitucionalidad por omisión. Por supuesto que, con el presente trabajo, no se tiene la pretensión de encontrar la solución perfecta a este problema, pero sí de contribuir en aras al equilibrio entre la función jurisdiccional y el papel del legislador.

* Este artículo contiene resultados del proyecto de investigación: "Recepción de estándares internacionales de protección aplicables a un proceso penal que investigue la comisión de graves crímenes internacionales, por parte del ordenamiento jurídico colombiano", que hace parte de la línea de investigación: "Fundamentos e implementación de los Derechos Humanos" del grupo de investigación "Persona, Instituciones y Exigencias de Justicia", vinculado al Centro de Investigaciones Sociojurídicas (CISJUC), adscrito y financiado por la Facultad de Derecho de la Universidad Católica de Colombia. Investigación con colaboración de la Universidad Nacional de Asunción. Paraguay.

1 Es dable señalar, que quizás no desarrollaremos estas cuestiones en forma amplia y acabada, simplemente en forma tangencial e indicativa, a los efectos de reflexionar sobre dicho instituto y su importancia. 
De manera que, uno de los más novedosos medios de control de constitucionalidad es la inconstitucionalidad por omisión legislativa, como su nombre lo indica, tiene como finalidad controlar la regularidad del orden jurídico ante las omisiones en que incurren los órganos legislativos, cuando se encuentran incumpliendo mandatos constitucionales para legislar y que, por tanto, no permiten que las normas de la carta fundamental desplieguen correctamente su eficacia jurídica.

A continuación, se hará un breve recorrido doctrinal, mostrando una visión panorámica en cuanto a su regulación en el extranjero, con la finalidad de tener una perspectiva general de esta, por lo que para ser diáfanos sobre el tema, nos hemos permitido una trascripción literal de algunas opiniones doctrinarias.

La inconstitucionalidad por omisión se produce cuando un órgano del Estado no ejecuta un deber constitucional, ya sea este expreso o tácito. Tal concepción se fundamenta en el principio de la supremacía constitucional, establecido por la Constitución como "un mandato o un deber para los poderes públicos". Por ejemplo, regular por ley una determinada materia, de modo que dichos poderes no pueden eludir sus obligaciones, dilatando indefinidamente su cumplimiento ${ }^{2}$, puesto que la Constitución no es un mero documento subordinado a la voluntad política de los gobernantes de turno: su fuerza normativa obliga y vincula. En consecuencia, la totalidad del ordenamiento jurídico, es decir, las normas infraconstitucionales y los hechos, actos u omisiones, tanto de autoridades como de particulares, que se encuentran compelidos bajo la supremacía constitucional (Bidart, 1995, p. 468).

Sin embargo, la realidad evidencia un grave problema respecto de la vigencia de los derechos humanos: la contradicción existente entre la norma, generosa en el reconocimiento de los derechos, y los hechos, plagados de ejemplos de violaciones a esos derechos. La gravedad de la situación se acentúa, en lo que respecta a los denominados derechos económicos, sociales y culturales, de los cuales la misma Convención Americana de Derechos Humanos establece para su efectivización, un desarrollo progresivo sujeto a la disponibilidad de recursos por parte del Estado (art. $26 \mathrm{CADH}$, y arts. 1 y 2 del Protocolo de San Salvador). Estos derechos, se caracterizan principalmente por la actividad positiva que requieren del Estado para su efectiva realización, y ello explica por qué son las omisiones la forma normal por la cual son vulnerados los mismos ${ }^{3}$.

2 Tal como lo fue la creación de leyes relativas al fuero de la niñez y la adolescencia, adolescente infractor, la creación de fueros especializados e instituciones públicas protectoras de los derechos de los niños (v.gr. Codeni, etc.), que luego de 11 años de firmarse el tratado, recién fueron creados y en forma parcial. Los ejemplos abundan, la falta de ley reglamentaria sobre el derecho de peticionar las autoridades, la objeción de conciencia, entre otros.

3 Si se limita la eficacia de las garantías previstas en los ordenamientos jurídicos solo para aquellos supuestos en que la violación de los derechos se verifica, a través de conductas positivas del Estado o de particulares, se dejaría de lado el control de su afectación por medio de omisiones, estos derechos de naturaleza socio-económica se verían significativamente menguados, careciendo en la práctica de valor normativo alguno. 
Al respecto, Néstor P. Sagües sostiene que en Argentina:

Más allá de esa ausencia de normativa expresa, la jurisprudencia de tanto tribunales inferiores como de nuestro máximo tribunal, estudiada en esta investigación, muestra una tendencia hacia el reconocimiento de la posibilidad de subsanar esa falencia a través del amparo regulado por el art. 43 de la Constitución Nacional, exigiendo a través de ese control judicial el cumplimiento de las obligaciones positivas de los órganos estatales. Evidentemente, estos pronunciamientos han implicado un avance hacia el reconocimiento de garantías idóneas tendientes a la tutela de derechos. Si bien muchas veces pueden plantearse reparos teóricos o doctrinarios, es necesario ahondar en el análisis explorando nuevas variables, y ampliar los márgenes clásicos de control (Sagues, 2002, p. 617).

Para finalizar esta breve introducción e invitarlos a consultar el informe final de la investigación, resulta oportuno recordar la opinión de Bidart Campos cuando decía:

Comprendemos muy bien que la doctrina de la supremacía suministra argumentos para sostener que la Constitución se vulnera no solamente cuando se hace lo que ella prohíbe hacer, sino también cuando se deja de hacer lo que ella manda que se haga. No hay zona alguna de reserva que el Ejecutivo, el Congreso, o la Administración puedan invocar para eximirse de hacer lo que la Constitución manda que hagan (Bidart, 1995).

Ahora bien, este trabajo, contendrá un estudio breve, pero indispensable, de las condiciones teóricas sobre la inconstitucionalidad por omisión legislativa, que servirán de base para el posterior desarrollo de temas como su tratamiento en algunos países, cuyas legislaciones han incorporado la figura de mérito, a su vez analizará diversas sentencias de la Corte Interamericana de Derechos Humanos (en adelante Corte IDH), para aportar al concepto de omisión legislativa convencional, la cual surge cuando los Estados no toman en cuenta los diferentes fallos. Para finalizar, con los anteriores antecedentes se denota una necesidad de incluir a la inconstitucionalidad por omisión legislativa en los diferentes ordenamientos jurídicos que versen sobre este tema ${ }^{4}$.

4 En ese sentido, es dable señalar que nuestro país ratificó por Ley $\mathrm{N}^{\circ}$ 57/90 la Convención de las Naciones Unidas sobre los Derechos del Niño, que en su artículo 40 inciso $3^{\circ}$ establece que: "Los Estados Partes tomarán todas las medidas apropiadas para promover el establecimiento de leyes, procedimientos, autoridades e instituciones aplicables específicamente a los niños...”, sin embargo, recién por Ley $\mathrm{N}^{\circ}$ 1680/2001 se sancionó el "Código de la Niñez y la Adolescencia”, es decir, 11 años después, y quizás por la presión internacional, ya que la Comisión de Derechos Humanos podría solicitar la sanción de nuestro país, por incumplimiento de la Convención de las Naciones Unidas sobre los Derechos del Niño" (Negrillas fuera del texto original). 


\section{EL CONCEPTO DE OMISIÓN LEGISLATIVA}

\section{Precisión terminológica}

Son múltiples las perspectivas desde las cuales se examina el contenido de omisión legislativa, sin que exista coincidencia siquiera en relación con la terminología empleada para identificar la figura. Esto se explica por diferencias de criterio respecto de su significación o alcance, por la variada regulación del instituto, o la ausencia de esta, en los distintos países en que ha sido objeto de estudio.

Se suele emplear la expresión inconstitucionalidad por omisión para referirse a la figura, pero hay diferencias importantes al definir la multiplicidad de situaciones comprendidas en ella. Así, algunos autores emplean tal expresión para aludir a violaciones de la Constitución derivadas no de una acción, sino de una omisión del legislador; y solo de este; en cambio, otros, bajo la óptica del ordenamiento jurídico que analizan, incluyen dentro de la inconstitucionalidad por omisión los diversos supuestos de inconstitucionalidad originados en la falta de producción de normas jurídicas, aunque no deban emanar del legislador, como sucede en la doctrina argentina, dado que la Constitución de la Provincia de Río Negro, única que contiene en ese país una regulación específica sobre la materia, no limita la acción de inconstitucionalidad por omisión al ámbito de actuación del legislador (provincial) (Sagues, 1998, pp. 175 y ss).

Por otro lado, algunos consideran más exacta la alusión a la "dejación o inactividad" del legislador, por la vinculación del término omisión al Derecho Penal y a la responsabilidad individual, mientras que para otros el vocablo inactividad posee una neutralidad de la que aquél carecería, al estar el concepto de omisión relacionado con la infracción de normas jurídicas, por lo que consideran preferible este último.

En este sentido, es frecuente observar en la doctrina que el concepto de omisión legislativa, implica por sí solo la inobservancia de la Constitución, mientras que se acude a los términos inactividad o silencio cuando la pasividad del legislador no es censurable constitucionalmente, dado que la Constitución a menudo faculta al legislador, pero no lo obliga a legislar en una materia determinada ${ }^{5}$.

A modo de aclaración, es importante mencionar que en vista de tales divergencias, resulta conveniente reiterar que en este trabajo se analizan los silencios o la inactividad del legislador desde la perspectiva del control judicial dirigido a proteger la Constitución de las violaciones a sus preceptos que de aquellos puedan derivarse.

Escapa a nuestros fines el examen del control judicial de la inactividad de la administración o de otros órganos del poder público en la adopción de normas cuya aprobación imponga el ordenamiento jurídico. Esta delimitación del ámbito de estudio encuentra justificación en la peculiaridad y trascendencia jurídico-constitucional de los problemas que plantea el control judicial de las omisiones legislativas. Por otro lado, la expresión omisión legislativa será usada como sinónimo de inconstitucionalidad por omisión, a menos que del contexto se desprenda que se emplea en el sentido neutral antes señalado. 


\section{La omisión legislativa (Inconstitucional)}

Al aludir a la omisión legislativa, obviamente nos estamos refiriendo a una inactividad del legislador en el desempeño de la función que, a pesar de las transformaciones operadas en el Estado constitucional, sigue marcando su distinción de las otras ramas del poder público: la de dictar leyes.

Por lo anterior, es importante mencionar que la omisión legislativa se produce cuando el legislador no observa, en un tiempo razonable o en el que haya sido fijado constitucionalmente, por la Constitución, o cuando, en el cumplimiento de la función legislativa, se dicta una regulación no acorde con la Carta Magna por haber sido omitidas previsiones que la Norma Suprema exigía.

Partimos, pues, de un (i) concepto amplio de inconstitucionalidad por omisión legislativa, ya que no la circunscribimos al cumplimiento de mandatos constitucionales concretos de legislar, ni forma parte del concepto la falta de desarrollo de tales preceptos durante un tiempo "excesivamente largo" preponderantemente temporal de la inconstitucionalidad por omisión, (ii) no abarca el universo de situaciones que pueden estar comprendidas bajo la inconstitucionalidad por omisión, y (iii) resulta limitada de las posibilidades de defensa de la Constitución ante las omisiones legislativas.

Es importante recalcar que, la omisión legislativa inconstitucional se produce no sólo cuando se desconocen mandatos concretos de legislar, sino también cuando se regula una materia de manera incompleta o deficiente desde el punto de vista constitucional.

Además, para la existencia de una inconstitucionalidad por omisión no siempre se requiere del transcurso de un tiempo "excesivamente largo". Este elemento temporal es irrelevante cuando nos hallamos ante una omisión relativa del legislador fundada en la violación del principio de igualdad, por ejemplo. Pero cobra relevancia ante las omisiones legislativas, absolutas o relativas, vinculadas al desarrollo de mandatos concretos de legislar, o encargos al legislador, en la terminología de Fernández Rodríguez. Resulta preferible aludir, siguiendo a Sagües, al concepto de "plazo razonable", no exento de contornos poco nítidos pero preferible a expresiones y visiones que ponen al acento en la discrecionalidad del legislador en la elección del momento en que ha de ser desarrollada una norma constitucional.

Ahora bien, la alusión a la existencia de un mandato concreto de legislar, que tiene importancia en relación con algunas de las manifestaciones de la inconstitucionalidad por omisión, parte de la distinción entre las exigencias constitucionales concretas de legislar y el deber general de legislar que puede colegirse de ciertas normas, -fin o normas- tarea abstractamente impositiva contenida en las Constituciones?

6 Como sostiene Fernández Rodríguez, pp. 85-86, entre otras.

7 Entre las primeras se encontrarían, según Gomes Canotilho, las normas de la Constitución portuguesa que obligan al establecimiento y la actualización del salario mínimo legal; a la 
Así pues, la falta de desarrollo de estos principios sería contraria a la Constitución, "pero su concreción, depende esencialmente de la lucha política y de los instrumentos democráticos" (Gómez, 1993, pp. 1089-1090). De modo que se suele considerar que ni de los valores superiores o principios constitucionales, ni de la Constitución como conjunto normativo puede derivarse un mandato concreto de legislar. Esto resulta aceptable hasta un cierto punto. Así, cabe afirmar que del reconocimiento del valor superior de libertad y de la justicia, o de la proclamación del Estado como un Estado social, no se deducen tales mandatos.

Pero, no puede rechazarse de plano la presencia de estos en normas contentivas de principios constitucionales, sobre todo si tenemos en cuenta los diversos sentidos en que se usa este concepto, que incluso se emplea para referirse a los derechos fundamentales. En cualquier caso, importa observar que la imposibilidad de calificar una norma constitucional como generadora de un mandato concreto de legislar no implica que deba quedar fuera de consideración al apreciar la existencia de una inconstitucionalidad por omisión, ya no por falta de desarrollo del mandato, sino por la regulación incompleta o deficiente de alguna materia, en contravención de la Constitución.

La referencia a un mandato constitucional de legislar, implica que el legislador carece de libertad en cuanto a la determinación de la necesidad del desarrollo legislativo, pues el mandato entraña una orden o exigencia relativa a la aprobación de una norma.

No obstante, se ha criticado la inclusión de los supuestos en que el legislador permanece "pasivo o silente" ante un mandato de legislar, particularmente cuando nos hallamos ante una omisión absoluta y la Constitución no ha fijado un plazo para la aprobación de la normativa respectiva.

En ese sentido se ha expresado:

...El hecho de que la Constitución no imponga alguno de los cometidos encomendados al legislador debe interpretarse, como un permiso al legislador para que sea él quien decida sobre el momento oportuno para realizar la encomienda. Ese juicio de oportunidad pertenece al ámbito competencial del legislador y a nadie más. Por este motivo, la cuestión del plazo es irrelevante para determinar si el silencio vulnera o no la Constitución, pues la existencia de la vulneración es independiente del transcurso del tiempo. El plazo, si la Constitución no lo impone expresamente, pertenece, a estos efectos, al mundo de la decisión política, no a la jurídica. El deber constitucional no consiste en hacer algo en un determinado plazo, sino en hacerlo desde el momento en que la Constitución está vigente; aunque la fijación de ese momento quede a la decisión del legislador. Si éste puede decidir sobre cuándo cumplir con el permiso a la orden constitucional, su inactividad puede interpretarse

organización, coordinación y financiamiento de un sistema de seguridad social y unificada y descentralizada; y a la creación de un sistema nacional de salud. Entre las segundas, relacionadas con un deber general de legislar, se mencionan los principios rectores de la organización económica. 
sin más, contraria a la Constitución. La existencia del permiso constitucional sobre la determinación del momento temporal para cumplir la encomienda constitucional hace preciso, para trasformar el silencio legislativo en una omisión inconstitucional, que ese silencio conserve o genere una situación contraria a la Constitución.

Siguiendo lo anterior, la existencia del permiso constitucional sobre la determinación del momento temporal para cumplir la encomienda constitucional hace preciso, para trasformar el silencio legislativo en una omisión inconstitucional, que ese silencio conserve o genere una situación contraria a la Constitución. Este es el preciso instante en el que se infringe la Constitución, y no a partir del cómputo de cierto plazo razonable para cumplir con el mandato o permiso constitucionales (Villaverde, 1977, p. 44).

A nuestro juicio ${ }^{8}$, el enfoque del autor, aunque tiene la virtud de poner de relieve la pluralidad de respuestas jurídicas articulables ante las omisiones legislativas y sus efectos, excluye sin razón del concepto de omisión inconstitucional supuestos que indudablemente lo conforman, como la falta de desarrollo de mandatos constitucionales de legislar dentro de un plazo razonable. Además, no podemos compartir la tesis de que esté reservada al legislador la valoración sobre la oportunidad para la aprobación de las leyes exigidas por preceptos de la Constitución, por la circunstancia de que esta no haya precisado "el plazo específico" que en cada una debe ser dictada. Por otro lado, la admisión de una acción directa y abstracta contra omisiones absolutas del legislador, dependerá de la regulación de cada ordenamiento jurídico, y obviamente no impide la protección de la Constitución ante situaciones concretas lesivas de sus preceptos derivados del silencio legislativo, aun antes de que este parezca ser censurado, en abstracto, por inconstitucional. En el examen de la constitucionalidad de estas situaciones concretas, la razonabilidad del tiempo transcurrido puede jugar, por cierto, un papel relevante y en ocasiones determinante.

De este modo, es determinante, cuando del propio precepto constitucional se deriva la necesidad de adaptar algunas situaciones jurídicas a las circunstancias imperantes en cada momento9. El paso del tiempo, igualmente puede ser relevante en los casos de inconstitucionalidades por omisión que se derivan no de la completa ausencia de una regulación legal posconstitucional sobre alguna materia, sino de la falta de adaptación o mejora de tal regulación, ante un cambio de circunstancias que se aparta del pronóstico que sirvió de base a la legislación existente.

Finalmente, es preciso referirse a una vertiente formal del concepto de omisión legislativa, como la distinción entre los casos en que la inconstitucionalidad se subsume en el esquema clásico de las acciones legislativas y los que pertenecerían

$8 \quad$ Es simplemente una opinión personal, respetando desde luego las opiniones doctrinarias.

9 Así, en Argentina, la Corte Suprema de Justicia de la Nación, al conocer un recurso extraordinario contra la sentencia dictada en una acción de amparo interpuesta por jueces que consideraban vulnerada la garantía de intangibilidad de las remuneraciones judiciales reconocida por la Constitución argentina, confirmó la protección de los actores ante la falta de actualización de sus sueldos a pesar de la inflación producida, omisión imputable al legislador. 
a la categoría de las omisiones legislativas. Al respecto, ha sido defendida la tesis de la intercambiabilidad entre impugnaciones por comisión o por omisión, según esta, la inconstitucionalidad por omisión observada en una ley siempre podría ser reconducida a una inconstitucionalidad por comisión o acción de la misma ley, por lo que la diferencia entre ambas categorías sería solo una cuestión de perspectiva, carente de contenido sustancial.

Siguiendo lo anterior, es importante mencionar que tal tesis se ha propuesto, lógicamente, respecto de las omisiones relativas, pues es aquí donde podría presentarse la confusión. Estimamos, sin embargo, que sí existe una diferencia objetiva entre ambas modalidades: la inconstitucionalidad por acción legislativa se produce cuando lo sostenido o establecido en el texto legal es contrario a la Constitución, mientras que la inconstitucionalidad por omisión legislativa existe cuando el vicio de la ley reside no en el o qué dice, sino en lo que calla. En ambos supuestos, es posible referir directamente la ilicitud de la ley a lo afirmado en artículos, párrafos, frases o incisos de un precepto legal, en tanto que en el segundo ello no será posible, al estribar la ilicitud de la ley en su silencio o parquedad, contrarios a una exigencia constitucional. A continuación, se analizará de manera detallada lo expuesto anteriormente.

\section{Antecedentes}

La nueva Constitución de Ecuador, aprobada por referéndum el 28 de setiembre de 2008, ha remodelado con cierta intensidad al antiguo Tribunal Constitucional ${ }^{10}$ que existía en tal país, que con distintos nombres y competencias, es uno de los más antiguos de América Latina. En términos generales, ha reforzado sus roles y aumentado su autonomía ${ }^{11}$.

10 La nueva Constitución declara a la Corte Constitucional como el máximo órgano de control de la constitución (art. 429). Se integra con nueve miembros, que duran nueve años sin reelección inmediata (art. 432), período felizmente ampliado con relación al corto tramo anterior de cuatro años. No están sometidos a juicio político. No pueden ser removidos por quienes lo nombraron. En caso de responsabilidad penal son enjuiciados por la Corte Suprema de Justicia. Su destitución se decide por los tercios de los miembros de la Corte Constitucional (art. 431). Sus miembros son designados por una Comisión Calificadora de seis miembros (dos designados por la función legislativa, dos por la ejecutiva y dos por la de Transparencia y Control Social), mediante concurso público: Art. 435. La función de Transparencia y Control social se forma por el Consejo de Participación Ciudadana y Control Social, la Defensoría del Pueblo, la Contraloría General del Estado y las superintendencias (art. 204). En la práctica, habrá que analizar en el futuro si la Comisión Calificadora concluye o no efectivamente libre de influencias de los otros poderes del Estado. La autonomía funcional de la Comisión será un dato indispensable para exigir una Corte Constitucional a su vez imparcial e independiente.

11 La labor de exponer en forma diáfana y coherente este tema, se dificulta dado que esta figura ha sido conceptualizada en formas muy diversas en los países que ya la han adoptado, en sentidos amplios y restringidos, considerando únicamente al Poder Legislativo y en otras también se incluye al Ejecutivo; igualmente se le han impreso características propias, en cuanto a los sujetos legitimados, los efectos de sus resoluciones, las alternativas de solución, etcétera. 
Nos interesa detenernos en un aspecto de la reforma constitucional de la República de Ecuador, referente a la inconstitucionalidad por omisión. El actual inciso 10 del artículo 436 de la Constitución se detiene específicamente en el tema y dispone lo siguiente, entre las competencias de la nueva y ahora denominada Corte Constitucional:

Declarar la inconstitucionalidad en que incurran las instituciones del Estado o autoridades públicas que por omisión observen, en forma total o parcial, los mandatos contenidos en normas constitucionales, dentro del plazo establecido en la Constitución o en el plazo considerado razonable por la Corte Constitucional. Si transcurrido el plazo la omisión persiste, la Corte, de manera provisional, expedirá la norma o ejecutará el acto omitido, de acuerdo con la ley (Negrilla fuera del texto original).

Como puede constatarse, de haber una intimación por parte de la Corte Constitucional, la cláusula habilita a la misma Corte para que, de manera provisional, emita la norma ausente o ejecute el acto omitido, de conformidad con la ley.

A su vez, esta norma es similar a la sancionada para el Estado de Chiapas (México), por decreto publicado en el periódico oficial del 16 de mayo de 2007, según la cual, cuando se considere que el Congreso no ha resuelto alguna ley o decreto y que dicha omisión afecte al debido cumplimiento de la Constitución, el Tribunal Constitucional del Estado intimará al Congreso para que resuelva la omisión en un período de sesiones, y si no lo hace, el referido Tribunal Constitucional se pronunciará en torno a la omisión, emitiendo provisionalmente las disposiciones pertinentes, añadiendo "que dicha legislación estará vigente hasta que el Congreso subsane la omisión legislativa" (art. 56, fracción III de la Constitución del Estado).

No es preocupante que un órgano de la jurisdicción constitucional, ante un caso de omisión inconstitucional, ordene cumplir un acto concreto omitido. Esto es frecuente en el derecho procesal constitucional, y para ello existen, habitualmente, acciones de amparo o mandamientos de ejecución. Pero, lo que sí llama la atención es la habilitación constitucional para que, ante supuestos de omisión inconstitucional en la producción de normas generales, el referido tribunal pronuncie la regla jurídica ausente de manera provisional.

No obstante, hay múltiples remedios jurisprudenciales y constitucionales para atacar a la inconstitucionalidad por omisión. Basta mencionar, al respecto, sistemas que contemplan una denuncia ante el órgano que controla tal omisión, y otros que pueden proseguir con recomendaciones, llamados de atención o intimaciones al órgano en mora, la cobertura judicial para un caso concreto, la imposición de un resarcimiento por el daño causado, etc.

Con referencia específica a la actuación de una Sala o Tribunal Constitucional como legislador suplente, y sin pretender agotar la temática, es posible citar a la Constitución de Venezuela de 1999, que en su art. 336 inc. $7^{\circ}$, al contemplar la inconstitucionalidad por omisión en la generación de normas por parte del poder legislativo nacional, estatal o municipal, establece que la Sala Constitucional 
del Tribunal Supremo de Justicia "establecerá el plazo y, de ser necesario, los lineamientos de su corrección". Aquí ya se anticipa una gestión como legisladora positiva de la Sala Constitucional, respecto del posible contenido que deberá tener la futura norma a dictarse.

Por lo anterior, es importante recordar el caso de la Constitución del Estado Mexicano de Veracruz, y con alusión a la mora legislativa inconstitucional del Congreso, cuando estatuye que el Tribunal Superior de Justicia fija un plazo de dos períodos ordinarios de sesiones, para que elabore a la norma faltante; y si "transcurrido este plazo no se atendiere la Resolución, el Tribunal Superior de Justicia dictará las bases a que deban sujetarse las autoridades, en tanto se expide dicha Ley o Decreto".

En esta hipótesis, el perfil del Tribunal Superior de Justicia como legislador suplente tiende a definirse más. Se trata de su aptitud constitucional para "dictar las bases" que regularán el tema hasta tanto lo haga el legislador ordinario. Para Fernández Rodríguez, está potenciado para emitir "una especie de normativa básica" (2003, p. 3771).

Pero en el caso ecuatoriano, aproximándose a la alternativa seguida en Chiapas, tal definición es todavía más categórica, ya que, como vimos, consiste en que la Corte Constitucional "expedirá" la norma ausente, bien que de manera "provisional" y conforme a la ley.

\section{Fundamento de la solución constitucional}

En el presente apartado del texto seguiremos a varios autores, dada la limitada posibilidad que se tiene de desarrollar ampliamente los temas por tratar, y debido a que resulta indispensable contar con ciertas bases para poder arribar a la parte final de ese estudio. Así pues, para comenzar conceptualizaremos la inconstitucionalidad por omisión legislativa.

Comencemos por “omisión”, el Diccionario de la lengua española, nos dice que proviene del latín omissio, onis, que se refiere a la "abstención de hacer o decir"; "falta por haber dejado de hacer algo necesario o conveniente en la ejecución de una cosa o por no haberla ejecutado" (Real Academia de Lengua Española, 2001, p. 1620). Trasladando esto al ámbito jurídico, llama la atención que algunos diccionarios jurídicos, no contemplan dicho término (Pina, 1991; Caballenas, 1988) y otros remiten únicamente a aspectos penales (Instituto de Investigaciones Jurídicas UNAM, 2001). Por su parte, Guillermo Cabanellas afirma que la omisión es la "falta del que ha dejado de hacer algo conveniente, obligatorio o necesario en relación con alguna cosa", y respecto de la omisión de deberes dice que "el incumplimiento de los deberes activos impuestos a las autoridades origina, por la abstención, la responsabilidad de estas cuando han de actuar de oficio y también si desatienden los justificados requerimientos de los particulares o actúan sin celo o con malicioso retraso" (Cabanellas, 1988, p. 115). A pesar de que nuestra materia no es el derecho penal, como se dijo al hablar de omisión, resulta casi imposible no atender a esta 
rama, lo cual ha estudiado ampliamente dicho término, por lo cual, tomaremos en cuenta la definición que nos propone Marco Antonio Díaz de León:

La omisión es una manifestación de la voluntad que se exterioriza en una conducta pasiva, en un "no hacer". Pero no toda inactividad voluntaria constituye una omisión penal, es preciso para que ésta exista, que la norma penal ordene la ejecución de un hecho determinado (1986, p. 1186).

En cuanto al segundo elemento, la inconstitucionalidad se define como "antinomia entre un acto y la Constitución" (Capitant, 1986, p. 315), diremos que, "partiendo del principio inexcusable de la supremacía de la Constitución, se han de reputar como inconstitucionales todos los Actos, Leyes, Decretos o Resoluciones que se aparten de sus normas o las contradigan" (Osorio, 1992, p. 8).

En este punto, es importante mencionar que no pasa desapercibido el hecho de que en las definiciones apuntadas se hace referencia únicamente a conductas positivas, y nunca a las omisivas, esto se debe a que así fue la concepción durante mucho tiempo y no se aceptaba la idea de que un "no hacer" también pudiera violar la Constitución, pero como veremos, esta conducta pasiva del legislador, sí es contraria al texto constitucional, cuando existe un mandato para legislar, para expedir cierta reglamentación, o bien que en términos específicos, la norma constitucional delegue la reglamentación de alguna materia o hipótesis a la ley ordinaria, de modo que en ambos casos al no hacerlo así el legislador transgrede el texto constitucional, al no cumplir con su cometido, y con ello impide que se le dé exacto cumplimiento a la normativa constitucional.

Se concluye entonces lo relativo al concepto de aquella institución, diciendo que para José Julio Fernández Rodríguez:

La inconstitucionalidad por omisión la conceptualizamos como la falta de desarrollo por parte del Poder Legislativo, durante un tiempo excesivamente largo, de aquellas normas constitucionales de obligatorio y concreto desarrollo, de forma tal que se impide su eficaz aplicación (2003, p. 13).

Por otro lado, es notorio que en la receta ecuatoriana prevalece la intención de afirmar la fuerza normativa de la Constitución, entendida como regla motorizable por la Corte Constitucional, cuando la inacción del legislador regular del caso paraliza su eficacia. Esa suerte de anestesia inconstitucional de la Constitución, por la renuencia del legislador, es salvada así, de modo subsidiario y provisional, por la Corte Constitucional.

A su vez, es notorio que la Constitución ha querido que la vigencia de los derechos enunciados por ella no quede a la merced de la voluntad del órgano legislativo de sancionarlas o de no sancionarlas. La solución, ha sido dejar a la magistratura constitucional (en su máximo nivel) la cobertura transitoria de la norma faltante. Para ello, la Constitución "judicializa” el conflicto (que décadas atrás era una political question, o cuestión política no justiciable), y lo inserta de las competencias de la Corte Constitucional. 
Por supuesto, la primera crítica a este régimen es la hipotética violación del principio de división de poderes, dado que la Corte Constitucional estaría cumpliendo aquí funciones nomogenéticas encargadas por la Constitución, inicialmente, a otros órganos. Vale la pena observar que se trata aquí de una impugnación de tipo académico y conceptual, ya que no es una violación de la Constitución, desde el momento en que es la misma carta política la que programa al sistema que analizamos ${ }^{12}$.

Del mismo modo, cabe mencionar que el órgano presuntamente "invadido" mal podría considerarse "víctima", ya que si hubiese omitido la norma que no dictó, no existiría problema alguno. Nadie puede, según el viejo adagio latino, alegar su propia torpeza. Además, cada cual es responsable de sus propios actos (en la especie, de su propia omisión, infractora de la Constitución).

Al mismo tiempo, el citado órgano hipotéticamente "invadido" podría concluir inmediatamente, si lo quisiera, con la supuesta "invasión” de la Corte Constitucional. Como ésta actúa aquí "de manera provisional", si el órgano constitucionalmente previsto que no sancionó la norma, lo hace cumpliendo con su deber constitucional, ipso jure concluye la norma dictada por la Corte Constitucional. Las normas elaboradas por la Corte son, en definitiva, preceptos bajo condición resolutoria (sub conditionem resoluitur); de manera que tienen vigencia hasta tanto el legislador normal quiere mantenerlos, ya que puede sustituirlos con la norma que él desee sancionar, cumpliendo con el mandato constitucional que le obliga a aprobarla.

El fundamento de esta institución es un hecho que no puede ser negado. En primer lugar, tendríamos la presencia de cierto tipo de armas en la Ley Básica. En efecto, los constituyentes recogen una serie de aspiraciones y anhelos del pueblo, un conjunto de valores e ideas que se traducen en una serie de normas jurídicas y en un determinado contenido material por normas de diferente carácter y de distinto tipo, con la consiguiente repercusión en la intensidad de su vinculación. La imposibilidad fáctica y las exigencias de técnica legislativa dan lugar a que el legislador ordinario asuma la obligación de desarrollar determinados preceptos del texto básico para asegurar la efectividad de ese proyecto constitucional y la concreción del mismo. Es decir, la existencia de normas incompletas, como las denominaría (Larenz, 2003, pp. 249 y ss), se traduce en una serie de órdenes al legislador, que éste debe cumplir.

Tales normas, designadas de varias formas por la doctrina (imposições constitucionais y ordens de legislar por (Gómez, 1993), mandatos al legislador por (Rubio, 1993, p. 95), verbassungsauftrag, entre otras denominaciones, en Alemania), normas de eficacia limitada para nosotros, no son meras proposiciones declarativas, sino que son verdaderas normas jurídicas que necesitan conectarse con otras para originar su plenitud aplicativa. La existencia de este tipo de normas en la lex legun parece inevitable, dado lo que debe ser la ley que ocupa la cúspide del ordenamiento y las funciones a las que responde, requieren que su articulado no agote las diversas

12 Aplicable en nuestra legislación, por impero del art. 247 de la Constitución, pues dice que "El Poder Judicial es el custodio de la Constitución". 
instituciones y regulaciones. La base de todo este razonamiento, es la superioridad de la Constitución, tanto desde el punto de vista material como el formal, con las conocidas consecuencias que de ello se derivan, y la vinculación de la obra del poder constituyente. La Ley Fundamental se tiene que imponer también en el supuesto de que se incumpla el deber de legislar que requiere la concreción del programa constitucional. De manera que se vulnera tanto a través de la emanación de una norma que contradice su contenido, como omitiendo aquello a la que ella obliga ${ }^{13}$.

Asimismo, el carácter normativo del texto constitucional aporta más fundamentos para su defensa. En este orden de ideas, hay que afirmar que si la vulneración de una norma jurídica debe tener una sanción y la vulneración de una norma jurídica puede producirse por omisión; entonces, la vulneración por omisión de la Constitución debe tener sanción.

Pero los razonamientos no son tan sencillos, como pueda parecer ya que hay que encuadrarlos en el contexto global de la problemática planteada, de forma que las dificultades que despierta la instauración de la omisión inconstitucional no se pueden olvidar. Éstas giran en torno a i) la libertad de conformación del legislador, ii) el principio de la división de poderes, iii) las dificultades en cualquier aspecto de su articulación práctica y, iv) la incidencia en la naturaleza del Tribunal Constitucional, el coste económico o social, la conveniencia política, entre otros.

No cabe duda de las destacadísimas consecuencias que conllevan instauración o rechazo de esta figura. En el primer caso, la incidencia en la construcción del Estado Social, el fortalecimiento de la función trasformadora de la Constitución o la efectiva realización del proyecto constitucional, podrían venir coadyuvados por los mecanismos que traería aparejados la existencia de la inconstitucionalidad por omisión. En el segundo caso, rechazar el instituto, quizá fomentará el "fraude" constitucional, el fortalecimiento del Ejecutivo e, incluso, una alteración del texto básico ajena al procedimiento de reforma establecido, sin olvidar la desvalorización del carácter normativo de la Constitución Nacional.

\section{Clasificación}

Ahora bien, debe destacarse que la inconstitucionalidad por omisión legislativa tiene su origen en el hecho de que no todas las normas constitucionales pueden aplicarse directamente, sino que muchas de ellas tienen eficacia diferida, al requerir posterior detalle para su debida aplicación; al respecto, seguiremos a Gustavo Zagrebelski, y en cuanto a los tipos de normas:

Normas constitucionales de eficacia directa: cuando la estructura de la norma constitucional puede servir de regla en casos concretos, debe ser utilizada

13 "Si la Constitución se define como suprema, esa supremacía declinaría en su vigor y genuino sentido al arbitrio absoluto de un órgano del poder constituido, quien al omitir su deber constitucional "bloquearía" a la cláusula constitucional respectiva" (Sagüés, 1989, p. 170). 
directamente por todos los sujetos del ordenamiento jurídico, como los jueces, la administración pública, o particulares.

Normas constitucionales de eficacia indirecta: cuando la estructura de las normas constitucionales no es lo suficientemente completa, de manera que pueda servir como regla de casos concretos, su operatividad requiere una posterior intervención normativa por parte de las fuentes subordinadas. En esta categoría, se encuentran las siguientes: 1) Las normas constitucionales de eficacia diferida: normas de organización que necesitan una disciplina normativa, posterior a la establecida en la Constitución. 2) Las normas constitucionales de principio: muchas disposiciones constitucionales contienen la formulación de principios jurídicos. Necesitan de una posterior actividad de concreción que relacione el principio con los casos específicos. 3) Normas constitucionales programáticas: cada programa implica la asunción de un cierto criterio como principio de acción, pero éstas se refieren esencialmente a aspectos político-sociales (2005), (Silva, 2003).

Finalmente, no sería correcto dejar de mencionar la muy conocida clasificación de las omisiones legislativas, la cual ha sido elaborada y estudiada por Wessel, quien siendo retomado por Bazán nos dice:

en las absolutas hay ausencia total de la norma que debería regular una determinada situación jurídica fijada constitucionalmente. En las relativas, el legislador, al propulsar la norma para "obedecer" el mandato "constitucional", favorece a ciertos grupos y olvida a otros, o acuerda ventajas a unos que no son dispensadas a otros, pudiendo tentativamente las hipótesis ser refundidas siempre en la siguiente fórmula: habrá omisión relativa toda vez que en el cumplimiento del mandato constitucional ( o del tratado internacional sobre derechos humanos con jerarquía constitucional en los sistemas jurídicos que les acuerden jerarquía constitucional), el órgano legislativo encargado de efectivizarlo quiebre el principio de igualdad, o -como lo afirma Fernández Rodríguez- cuando se produzca una regulación deficiente a causa de la falta de "complicidad" (sic) de la norma" (Bazán, p. 105).

\section{La actividad del poder judicial y el principio de división de poderes}

El tema de control de constitucionalidad de las omisiones legislativas, constituye un capítulo más en la tensión constitucionalismo-democracia. Los defensores del argumento contramayoritario no se deben sentir muy a gusto ante la inminencia no solo de dejar el control de constitucionalidad en manos de los jueces, sino de permitir que un grupo de individuos que a todas luces carece de credenciales democráticas, tenga la facultad de dictar normas propias de los representantes popularmente electos.

Pero, al órgano judicial le está vedada la posibilidad de dictar normas en virtud del respeto por el principio de separación de poderes, mas basta ahondar un poco en la cuestión para descartar (o tal vez admitir tibiamente) la eventual atribución de la 
Corte Suprema de Justicia o de los Tribunales Constitucionales de control y sanción de las omisiones legislativas.

Al respecto, se señala que el control de constitucionalidad de las omisiones legislativas, que producen una vulneración de la Carta Magna, contraría el principio de división de los poderes, por cuanto atenta contra la libertad de configuración normativa o discrecionalidad del legislador, el cual debe conservar la facultad de determinar el momento en que ha de ser desarrollado un precepto constitucional. Asimismo, se sostiene que puede resultar muy conveniente reconocer al legislador la posibilidad de dejar en suspenso previsiones constitucionales poco realistas que hayan sido aprobadas en medio del fragor revolucionario que a menudo acompaña la labor de las asambleas constituyentes. También, se alude a la amenaza que se cierne sobre las funciones propias del legislador lo que, a la vez, coloca a los jueces en riesgo permanente de incurrir en una usurpación de atribuciones. Por último ${ }^{14}$, se trae a colación el peligro de la llamada politización de la justicia constitucional, más aún cuando la omisión legislativa no es producto de una inadvertencia del legislador sino de una decisión deliberada.

Siguiendo lo anterior, es importante mencionar que la doctrina clásica de la división o separación de poderes determina que solo el órgano legislativo puede dictar leyes, abrogarlas, derogarlas o modificarlas. Asimismo, al órgano ejecutivo se le reconocen constitucionalmente amplias normativas. Los Tribunales Constitucionales fueron concebidos por (Kelsen, 1988) como legisladores negativos, en el sentido que pueden anular, eliminar o expulsar del orden jurídico las normas que contrarían los preceptos de la Carta Magna, ejerciendo una potestad de carácter eminentemente negativo con referencia a la Ley.

En la actualidad, este modelo es insuficiente. Paulatinamente se va demostrando que la tarea crucial de los Tribunales Constitucionales o Salas Constitucionales es la interpretación de los preceptos constitucionales. Esto, supone suministrar a jueces, legisladores, abogados y funcionarios criterios orientadores generales relativos, no solo al sentido de las cláusulas constitucionales; sino, a cómo deben interpretarse y aplicarse las leyes ordinarias, para que esa interpretación y aplicación se adecue a los mandatos de la Constitución. Lo cual se consigue, no sólo mediante las mencionadas sentencias interpretativas, sino también mediante orientaciones y advertencias a los poderes públicos, respecto de cómo debe entenderse la legalidad existente.

En efecto, la tarea interpretativa del Tribunal Constitucional se produce, al menos, por tres vías. La primera, y más evidente es el recurso a las sentencias expresamente interpretativas, en las que los Tribunales Constitucionales, en la parte dispositiva de sus sentencias, determinan cuál debe ser la interpretación correcta de una ley para

14 En la enumeración de los argumentos en contra del control de constitucionalidad de las omisiones legislativas basados en el principio de separación de los poderes no pretendo ser exhaustivo sino meramente indicativo. 
que se adecue a los mandatos constitucionales ${ }^{15}$. La segunda vía, es la representada por las consideraciones interpretativas, realizadas en la fundamentación de todo tipo de sentencias, dirigidas a establecer, de los posibles sentidos de un mandato constitucional cuál debe considerarse correcto. Y finalmente, la tercera vía sería la representada por las sentencias recaídas en casos de defensa de derechos individuales, en cuanto correctoras o confirmadoras de la interpretación de las leyes y la Constitución, llevada a cabo por los demás poderes públicos.

Sin embargo, la doctrina iuspublicista contemporánea desecha el dogma de la división de los poderes como un principio rígido que separa las funciones del Estado, asignándolas a órganos diferenciados y con ámbitos de actuación exclusivos. Por el contrario; la interacción y coordinación de poderes parece ser la regla de oro de una sana administración, de suerte que los tres órganos son legisladores, ejecutores y aplicadores de sus normas. El respeto por los principios republicanos, en consonancia con nuestro diseño institucional, exige el diálogo entre poderes, más cercano a la idea de frenos y contrapesos de Madison que a la separación estricta de poderes de Montesquieu ${ }^{16}$.

Coincidimos con las apreciaciones de Bazán, citando a González, al respecto, por cuanto:

Al examinar el nutrido repertorio de prácticas sentenciales que en la actividad jurisdiccional comparada se viene diseñando, pareciera quedar en evidencia la necesidad de buscar nuevas respuestas, ante la insuficiencia del modelo del legislador negativo y la disfuncionalidad del binomio inconstitucionalidad -nulidad para hacer frente a las discriminaciones normativas, evitando la expulsión inmediata de la norma en cuestión-

La inconstitucionalidad por omisión parte del reconocimiento de que no existe la certeza de que el órgano legislativo corregirá la inconstitucionalidad.

En estos casos, la labor del Tribunal Constitucional, no consiste en castigar al legislador que deja de cumplir su mandato específico, sino tratar de dotar de plena eficacia al precepto constitucional que carece de ella, puesto que como poder constituido y como defensor de la Carta Magna, su tarea consiste esencialmente en perseverar por la plena aplicación de los enunciados constitucionales.

Así que, el razonamiento que impulse la labor del Tribunal Constitucional, Corte Suprema de Justicia, o Salas Constitucionales, debe ser eminentemente jurídico y no político y dado el caso que la inactividad legislativa no viole por sí misma la normativa constitucional, debe abstenerse de intervenir. Siendo el pueblo el autor último de la Constitución, la mera pasividad del legislador, en tanto incumplimiento de su función de producir normas, solamente puede ser fiscalizada por el pueblo. El

15 Sentencias que suponen no solo la interpretación de la ley ordinaria, sino también, ciertamente, una interpretación del sentido de los mismos mandatos constitucionales.

16 Art. 3 de la Carta Magna. “...El Gobierno es ejercido por los poderes Legislativo, Ejecutivo y Judicial, en un sistema de independencia, equilibrio, coordinación y recíproco control”. 
control político de su accionar (o, en el caso, su falta de accionar) corresponde a los representados.

En los párrafos siguientes, nos dedicaremos a analizar casos específicos de omisiones legislativas en Latinoamérica, con el fin de revisar y proponer una solución a ello.

\section{FORMAS DE SUPERAR LAS OMISIONES DEL LEGISLADOR}

Las omisiones del legislador deberían ser salvadas, aunque esto parezca una obviedad, por el propio legislador. De él se espera, que legisle y cumpla el mandato constitucional. Puede que sea solo cuestión de tiempo que el legislador detecta su falta y la enmiende. Sin embargo, la inactividad también puede ser deliberada, consciente; se alegarán entonces razones de presupuesto, cuestiones políticas, o quizás falta de acuerdo en el seno del Congreso o Parlamento.

Frente a la inacción del órgano legislativo, los Tribunales Constitucionales han ensayado diversas técnicas que buscan superarla: i) Las recomendaciones al legislador, seguidas, ono de un pronunciamiento sobre la constitucionalidad oinconstitucionalidad de la omisión, concebidas como una especie de pronunciamiento previo a la siguiente categoría; ii) Las sentencias apelativas o exhortativas, que admiten tres variantes: a. sentencias de delegación, b. sentencias de inconstitucionalidad simple o de mera inconstitucionalidad o declarativas de incompatibilidad sin nulidad, y; c. sentencias de inconstitucionalidad precaria que declaran que la norma todavía es constitucional o sentencias con resolución de aviso. iii) La declaración de inconstitucionalidad parcial cualitativa en los casos de omisiones relativas relacionadas con la violación del principio de igualdad; iv) Las sentencias manipulativas en sus vertientes aditiva y sustitutiva.

En aspectos generales, las nóminas que ensayan los autores son coincidentes con la expuesta, empero nos parece útil, señalar que la efectuada por (Hernández, 2000, p. 8), quien citado por Sagües menciona: a) Denuncia ante un órgano superior, que implica que, vista la omisión legislativa se haga del conocimiento de la autoridad jerárquicamente superior; b) La recomendación donde el órgano superior o de control, simplemente recomienda a la autoridad omisa que cumpla con su labor; c) El llamado de atención, como su nombre lo dice, no es más que una solicitud a la autoridad omisa; d) La intimación, que implica el otorgamiento de un plazo para que se llene el vacío legal; e) La cobertura, donde ante el incumplimiento de la autoridad, el juzgador dictará las bases temporales, mientras se expide la ley en cuestión; f) La cobertura y el resarcimiento, ante el incumplimiento se procede a integrar el orden jurídico y si esto no fuera posible, se estipula un resarcimiento a favor del denunciante; g) La compulsa constitucional, se presenta en los casos que las propias Constituciones determinan que no pueden ser incumplidas por falta de ley reglamentaria, de modo que el juez debe ingeniárselas para resolver la situación de mérito. 
A su vez, para un sano y eficaz empleo de los institutos mencionados, $\mathrm{y}$, a efectos de impedir su uso irrestricto con la consiguiente distorsión del sistema republicano, el límite a estos nuevos tipos de sentencias, que se añaden a la defensa genérica de la Constitución instrumentable mediante el control de constitucionalidad, debería estar dado por un ejercicio consciente y reflexivo de la autolimitación judicial y por el respeto inexcusable a la libertad de configuración normativa.

El recurso a estas sentencias, resalta el rol político de los Tribunales Constitucionales y el empleo oportuno que estos hagan de las mismas, revela un sistema jurídico comprometido con la realidad y respetuoso de la soberanía popular. En tanto que el uso desmedido de estos instrumentos, compromete la independencia del órgano judicial y la posiciona al bordo del descrédito; el factor determinante en el razonamiento del Tribunal Constitucional debe ser única y exclusivamente de índole jurídico, no político. De primar éste último, la legitimidad democrática cede paso a la usurpación de funciones y el empleo de estas nuevas sentencias, se parece peligrosamente a conceder indebidamente facultades legislativas.

Asimismo, el Tribunal Constitucional situado frente a un caso de inercia legislativa que violenta el mandato constitucional, debe hacer un balance previo que incluya la estimación del costo de los derechos en juego, antes de elegir el instrumento a utilizar para remediar la situación. Puede suceder que la simple recomendación efectuada al órgano legislador, signifique solamente una dilación más en el proceso tendiente a asegurar el íntegro cumplimiento del mandato constitucional. En este supuesto, los eventuales damnificados con la omisión legislativa, pueden llegar a ver el pronunciamiento judicial como una burla. En otras ocasiones, la constatación por el Tribunal Constitucional de la imposibilidad cierta de desarrollar la legislación necesaria, determinará que éste evite recurrir al empleo de una sentencia con resolución de aviso que, de antemano supone, no podrá ser cumplida. La prudencia debe ser la guía que acompaña en todo momento el accionar del Tribunal Constitucional.

Además, es fundamental en pos del cumplimiento del mandato constitucional, una visión de la democracia que haga hincapié en la deliberación que necesariamente debe seguir a la utilización de estas nuevas tendencias. Puesto que, el Poder Judicial no puede permanecer ajeno al principio de apertura a los intercambios de razones propios de una sociedad democrática, $\mathrm{y}$, en este contexto, funciona como un mecanismo asegurador de la deliberación de aquellos que voluntariamente se inserten en el debate acerca de materias de interés público. Con ello, se trata de asegurar el principio constitucional, histórico y filosófico de la democracia deliberativa, mediante decisiones que alcancen un acuerdo teórico incompleto, que autoricen el desarrollo de ese proceso deliberativo y no produzcan un corte en esa discusión intertemporal.

Las decisiones judiciales sobre aspectos relevantes de interés público no deben, pues, finalizar el debate, sino cerrarlo parcialmente y permitir, dentro de lo posible, la discusión posterior por los órganos democráticos responsables ante el electorado sobre aspectos nuevos o no completamente dilucidados en las sentencias judiciales (Racimo, 2006, p. 198). 


\section{Críticas}

El cuestionamiento ${ }^{17}$ más fuerte a la doctrina de la Corte o Tribunal Constitucional como legislador suplente y precario viene por otros lados. Mencionaremos tres argumentos: a) el técnico; b) el político; c) el funcional (Sagües, 2009, pp. 71-79).

\section{a. El argumento técnico}

Este apunta que dictar sentencias no es lo mismo que elaborar normas generales (meta del legislador). La preparación y redacción de una norma cuenta con técnicas específicas, bastantes exigentes por cierto (Muñoz \& Prieto, 1996, p. 76), que en la esfera académica han dado lugar, incluso, a maestrías especializadas, como la actualmente en curso de la Universidad de Buenos Aires. Por lo demás, requiere oficinas de información y de asesoramiento, con personal especializado y un material informativo puesto al día, en temas muchas veces complejos.

Así que, el dictado de una norma general exige empalmar el nuevo texto con las normas afines, circunstancia que obliga a tener muy en cuenta normas preexistentes, o modificarlas. De no tomarse esas precauciones, el principio de derogación tácita orgánica (lex posterior derogat priori) puede provocar abrogaciones no queridas por quien está operando como legislador, o desajustes normativos muy perniciosos para la seguridad jurídica.

Con esto quiere significarse que legislar no es un trabajo para cualquiera, y que una Corte Constitucional que quiera operar como legislador, aunque precaria y suplente, puede no ser el órgano más adecuado para estas nuevas funciones, que en principio resultan anómalas para el tribunal. De todos modos, si las asume, ello requeriría cuerpos especializadas dentro de la corte, para coadyuvar con eficiencia en dicho trabajo.

\section{b. El argumento político}

Desde este punto de observación, cabe mencionar que el oficio de legislar es políticamente muy significativo ( principalem actus regis, lo llamaba Santo Tomás de Aquino), y que, en un Estado democrático, requiere deliberación, confrontación de posiciones, demandas colectivas e ideologías, elaboración de fórmulas conciliatorias y transaccionales entre los diferentes grupos políticos que conforman la sociedad, y a menudo, adoptar opciones entre fórmulas contrapuestas, cuando la concertación no se obtiene, con la prudente medición de los efectos que ellas pueden tener en una colectividad.

17 Sobre el punto es importante mencionar que: esta institución es desarrollada únicamente en los lugares donde existen Tribunales Constitucionales, y excepcionalmente, en lugares donde existen Corte Suprema de Justicia, como el caso de la Argentina, que fue mencionado precedentemente. En otras obras, desarrollaremos el concepto de la importancia y oportunidad de la vigencia de este instituto en los lugares donde no existen Tribunales Constitucionales, ya que la presente ponencia solo se basará en dar un bosquejo del desarrollo de esta institución, sus bondades y debilidades, en los lugares donde fue acogido legalmente. 
Tal espacio, difícilmente se va a encontrar en el seno de una Corte o Tribunal Constitucional, donde la mentalidad y los estilos imperantes, así como el discurso jurídico, transitan por otros caminos. En cierto modo, media allí un clima más profesional, universitario y académico, en la tarea de hacer funcionar el derecho, que el propio de un Parlamento donde se sanciona ese derecho. Los jueces constitucionales, además, no tienen por qué sentirse comprometidos con los partidos e intereses sectoriales que, en cambio, anidan en los poderes Ejecutivo y Legislativo (y que es bueno que afloren y se contrapongan en el debate democrático). Antes bien, deben comportarse como sujetos imparciales e independientes, como por ejemplo exige el art. $8^{\circ}$ del Pacto de San José de Costa Rica. Es por ello, que el escenario judicial tampoco sea el más adecuado para generar normas, aunque ocasionalmente algunos tribunales, en ciertos países, hayan preparado proyectos de ley, en particular concernientes a la actividad judicial.

\section{c. El argumento funcional}

Se debe determinar en qué medida la asunción de roles normativos por una Corte Constitucional puede perturbar el desarrollo de las tareas jurisdiccionales corrientes de tal órgano. Por lo general, en el ámbito latinoamericano, las Cortes y Salas Constitucionales tienen una cantidad de trabajo, que no guarda relación con los recursos humanos y técnicos convenientes para asumirla. En otras palabras, resultan desbordadas por una catarata de procesos constitucionales de toda laya, concernientes tanto a la llamada "jurisdicción de la libertad" (protectora de los derechos personales), como a la "jurisdicción orgánica” (solución de conflictos de poderes y de controversias entre los órganos del Estado, por ejemplo).

En síntesis, pocos Tribunales Constitucionales han optado por una solución tan dura como la estadounidense, cuya Corte Suprema resuelve menos de cien causas por año. La mayoría se encuentra condenada a recibir, procesar y resolver miles de expedientes.

La cuestión es si ante el panorama, es factible sumar a las funciones de una Corte Constitucional, la de actuar como legislador activo (aunque fuere suplente y precario), ante los supuestos de inconstitucionalidad por omisión. Naturalmente, la respuesta (desde un punto de vista exclusivamente cuantitativa), va a depender del número de procesos jurisdiccionales o parecidos a tales que debe decidir, y del número de causas donde tenga que actuar como legislador. Ese cálculo es decisivo para no asignarle a una Corte Constitucional misiones materialmente imposibles, que son en sí profundamente antisistémicas. Un Tribunal o Sala Constitucional atiborrada de pleitos, y además, el legislador, tiene el serio riesgo de incumplir ambos cometidos. 


\section{Balance y replanteo ${ }^{18}$}

\section{Los obstáculos para la aceptación del control judicial de las omisiones legislativas y la tendencia a su superación}

\section{Consideraciones previas}

No es nueva en la doctrina constitucional la preocupación por las violaciones a la Constitución que pueden derivarse de la "inactividad del legislador", en relación con un mandato constitucional de legislar. A ello se refirieron Jellinek y Kelsen, y a partir de allí varios autores (Villaverde, 1977, pp. 23 y ss.). La conciencia sobre la vulnerabilidad de la Norma Suprema por omisiones legislativas no es, pues, exclusiva de la doctrina contemporánea.

El tema ha cobrado, sin embargo, especial relevancia al hilo del constitucionalismo social, así como en virtud del robustecimiento de los mecanismos de control judicial de la constitucionalidad de las leyes. La proclamación del carácter social del Estado y la proliferación en las Constituciones de preceptos de contenido socioeconómico, que se traducen en mandatos de desarrollo legislativo, han estimulado la reflexión sobre el modo de articular el control judicial de su cumplimiento.

Asimismo, el fortalecimiento de la justicia constitucional, que ha ido ocupando progresivamente mayores espacios en el control de la inconstitucionalidad legislativa, ha puesto de relieve la necesidad de examinar y combatir desde una óptica jurídica la inactividad del legislador que lleve aparejada una vulneración de la Constitución.

La novedad y, al mismo tiempo, la polémica vinculada a la inconstitucionalidad por omisiones legislativas (o inconstitucionalidad por omisión sin más) se origina básicamente en la determinación de las respuestas jurídicas que tal pasividad de legislador merece. Para algunos, la inactividad del legislador, particularmente la de carácter absoluto, ha de tener una lectura básicamente política, por lo que deben ser políticas las vías empleadas para superarla. Otros, sin negar la virtualidad jurídica de dichas omisiones, han dudado de la viabilidad, en términos prácticos, de su control jurídico (Kelsen, 1979, p. 310)

A continuación, nos referiremos a los principales obstáculos dogmáticos o prácticos, que han sido invocados para rechazar el control judicial de las omisiones legislativas y pondremos de manifiesto su debilidad o inconsistencia, concluyendo con una advertencia sobre los riesgos que ahora se ciernen sobre ese control, en un contexto más propicio a su desarrollo, esto sin cerrar lógicamente el debate sobre este tema, sino puntos críticos que deben ser considerados a prima facie.

Resulta importante aclarar, que al examinar estas objeciones doctrinales debe distinguirse entre aquellas referidas al control judicial de las omisiones legislativas

18 "Yo creo que los jueces deben tener en claro esa diferencia: no hacen el presupuesto, deben respetar la discrecionalidad, pero hay que poner límites. El activismo judicial consiste en eso, en avanzar hasta que se respeten los derechos humanos y los marcos institucionales" (Lorenzetti, 2007). 
y las que se circunscriben a una modalidad específica, poco extendido en el derecho comparado, de ese control, como lo es la acción directa de inconstitucionalidad por omisión.

La aclaratoria resulta pertinente, pues en ocasiones se confunden las objeciones al control judicial de las omisiones legislativas con las referidas a la existencia en un ordenamiento de una acción directa de inconstitucionalidad por omisión. Una cosa es sostener, por ejemplo, que las Cortes o Tribunales Constitucionales invaden la competencia constitucional del legislador cuando extienden a un sector omitido por la ley un beneficio contemplado en ella, con fundamento en el principio de igualdad, y otra muy distinta es afirmar que no corresponde a los órganos judiciales valorar, a través de un medio constitucional específico, la oportunidad adecuada para la aprobación de leyes relacionadas con preceptos que algunos siguen calificando como programáticos.

La incidencia de ambas formas de control judicial en las relaciones entre la jurisdicción constitucional y el legislador no es necesariamente igual. Además, en un sistema en el que el máximo órgano de la justicia constitucional, al conocer de la acción directa de inconstitucionalidad por omisión, solo puede "declarar" la existencia de una omisión legislativa contraria a la Constitución, como sucede en el derecho portugués, sin estar facultado para integrar la laguna jurídica que haya podido observar, ni para imponer plazos o lineamientos para la corrección de la inconstitucionalidad, la repercusión del control judicial sobre la esfera de actuación del legislador, será menor que la que puede originarse en una sentencia "aditiva", dictada en el marco de procesos tradicionales de inconstitucionalidad, por la cual se extiende una disposición legal a supuestos no comprendidos en su texto. Luego volveremos sobre algunos de estos asuntos.

\section{Las dificultades de implementación y los condicionamientos socioeconómicos}

Un primer grupo de argumentos contrarios al control judicial de las omisiones legislativas, resalta la imposibilidad o dificultad de articular dicho control, en lo que concierne a la capacidad para doblegar una eventual renuencia del legislador a regular alguna materia, o a las restricciones económicas que pueden hacer inviables ciertas "promesas" constitucionales.

Ya en los inicios del sistema concentrado de control de la constitucionalidad, de acuerdo con Jiménez, Kelsen observó:

Hay una notable diferencia técnica entre los preceptos de la Constitución, que prohíben cierto contenido y los prescriben un determinado contenido en relación con leyes futuras. Por regla general, los primeros tienen efectos jurídicos, a diferencia de los segundos. Si el órgano legislativo expide una ley, cuyos contenidos están prohibidos por la Constitución, se producen todas las consecuencias que de acuerdo con la Constitución van enlazadas a una ley inconstitucional. Sin embargo, si el órgano legislativo 
deja simplemente de expedir la ley prescrita por la Constitución, resulta prácticamente imposible enlazar a esa omisión consecuencias jurídicas (Jiménez, 1998, p. 125).

Así, la declaratoria de la inconstitucionalidad de una ley, puede implicar su inmediata anulación $\mathrm{y}$, con ello, su expulsión del ordenamiento jurídico; mientras que la remoción de una omisión del legislador es más compleja, sobre todo si se trata de una omisión absoluta. Conviene, no obstante, diferenciar entre las variadas hipótesis posibles para evidenciar lo relativo de la objeción mencionada.

Entonces, las omisiones relativas o parciales del legislador a veces son reparadas mediante instrumentos tradicionales del control de la constitucionalidad de las leyes, como ocurre cuando se suprime del precepto legal impugnado un término o frase que atribuía a cierta categoría de personas un beneficio, para hacerlo extensible a otros sujetos $^{19}$.

Por el contrario, en otros supuestos, ante una omisión relativa o parcial, los Tribunales Constitucionales se han aventurado a extender mediante su sentencia a la categoría de sujetos, o a los casos no previstos por la ley sobre el beneficio o regulación legal, como después expondremos. Esta clase de sentencias puede ser cuestionada desde el punto de vista de su peligrosa penetración en la esfera funcional del legislador, pero no cabe duda alguna sobre su efectividad.

Además, si la omisión relativa o parcial se quiere reparar a través de una sentencia simplemente declarativa de la inconstitucionalidad, sumada a algunas exhortaciones al legislador sobre el tiempo y el modo en que tal reparación debe producirse, la efectividad del fallo es menor, pero no nula, pues a menudo esta clase de sentencias supone una oportunidad dada al órgano legislativo para la corrección de la inconstitucionalidad, antes de que sea planteado nuevamente el asunto, caso en el cual el Tribunal podría dictar, esta vez sí, un fallo anulatorio.

No obstante, el problema de la posible ineficacia o inviabilidad del control de constitucionalidad de los silencios legislativos se contrae, básicamente, a la corrección de las omisiones absolutas mediante acción judicial directa (control abstracto). Es cierto que, a través de este instrumento procesal es más difícil remediar la inconstitucionalidad legislativa (pasiva). El reconocimiento judicial de la existencia de un mandato constitucional de legislar inobservado, con valor meramente declarativo, como acontece con la acción de inconstitucionalidad por omisión en el derecho portugués, o la inclusión en la sentencia de una orden de legislar dirigida al Parlamento, como algunos entienden posible en el derecho brasileño, no garantizan la aprobación de la ley requerida por la Constitución.

19 Así, el Tribunal Constitucional español suprimió la expresión "la viuda" de un precepto de la legislación de seguridad social, para que los viudos también pudieran disfrutar, en las condiciones legalmente establecidas, de la pensión allí contemplada. 
Pero, la relativa eficacia de los pronunciamientos judiciales respectivos no es argumento suficiente para descartar su valor e importancia jurídica. Conviene recordar que la sola declaración judicial de la inconstitucionalidad de una acción u omisión del legislador, representa una consecuencia jurídica que no debe ser despreciada. Así lo han demostrado la doctrina y la praxis constitucional comparada en lo relativo a las sentencias simplemente declarativas de la inconstitucionalidad de un precepto legal (no anulatorias):

Al juez de la ley cavará sólo pedirle en muchos casos, y así será bastante, que constante el vicio denunciado y lo declare, rompiendo así la presunción de constitucionalidad de la ley. Tal es el contenido mínimo y esencial en su tarea" (Jiménez, 1998).

Algo similar ocurre, en relación con el control abstracto de constitucionalidad de las omisiones absolutas del legislador, pues, ante la imposibilidad de anular el silencio del legislador, puede emitirse una declaración judicial de inconstitucionalidad de la omisión legislativa, cuya consecuencia natural, será la adopción de la ley correspondiente por el órgano legislativo moroso.

Al margen del control abstracto de constitucionalidad, la solución explorada por el Derecho argentino, en la provincia de Río Negro, al regular la acción directa de inconstitucionalidad por omisión, consistente en facultar al Superior Tribunal de Justicia para integrar el orden normativo en el caso concreto, si la orden o intimación judicial de legislar no es atendida en el plazo fijado, e incluso para imponer una reparación indemnizatoria cuando la integración normativa no sea posible (Sagües en Bazan, pp. 109 ss.), así como la previsión de la Constitución de Brasil que faculta a ciertos Tribunales para proteger mediante amparo (mandado de injunção) a quienes sufran lesiones en sus derechos constitucionales u otras garantías, a causa de la ausencia de las normas de desarrollo necesarias; demuestran, además, que es posible establecer mecanismos jurídicos que aseguren eficacia en el control judicial de las omisiones legislativas.

Por consiguiente, el control de constitucionalidad de las omisiones legislativas alcanzaría su mayor eficacia si la máxima instancia de la justicia constitucional, estuviera facultada para establecer, -con efectos erga omnes aunque con carácter transitorio- la regulación imprescindible para dar operatividad al precepto constitucional no desarrollado legislativamente. Esta posibilidad, aunque propugnada por algunos autores, como (Da Silva, 1992) tiende a ser descartada por la doctrina y no ha sido admitida en la legislación comparada, relativa a la jurisdicción constitucional, por lo que la dejamos momentáneamente de lado. Luego veremos, que en ocasiones la jurisprudencia constitucional, al toparse con una omisión legislativa, ha procedido a integrar el orden normativo, hasta que el legislador intervenga -entre nosotros últimamente bajo la denominación de jurisdicción normativa-. Lo cual, dentro de los estrechos límites que más adelante intentaremos esbozar, resulta aceptable. 
En otro orden de ideas, antes apuntábamos que se ha puesto en duda la viabilidad del control de constitucionalidad de las omisiones legislativas en consideración a las restricciones económicas que con frecuencia impiden desarrollar mandatos constitucionales de contenido social, por lo que una intervención del Poder Judicial, dirigida a imponer su cumplimiento carecería de virtualidad práctica y llegaría a comprometer su autoridad.

Al respecto, es preciso aclarar que el control de constitucionalidad de omisiones legislativas, en sus plurales manifestaciones, no siempre se enfrenta con el problema señalado; éste se plantea sobre todo en relación con la acción específica y directa de inconstitucionalidad por omisión legislativa. Pero, el reconocimiento de tal acción no implica que se crea en una especie de fuerza de las sentencias, como tampoco es una invitación a que el Poder Judicial adopte decisiones políticas o de gobierno que no le competen. Es cierto que las restricciones económicas pueden obstaculizar el desarrollo de mandatos constitucionales legislativos, pero ello no prueba que el control de constitucionalidad de las omisiones legislativas esté desprovisto de sentido práctico. A menudo, a pesar de existir recursos disponibles, el legislador omite el cumplimiento de esos mandatos constitucionales, lo cual puede dar lugar al ejercicio del control de constitucionalidad, aunque con las limitaciones arriba mencionadas, en lo que respecta a su eficacia.

Es pertinente recordar que, en materias vinculadas a muchas exigencias constitucionales de desarrollo legislativo, los Estados han asumido obligaciones internacionales, como sucede en el ámbito de los derechos económicos, sociales y culturales. En este campo, los respectivos tratados internacionales admiten que el grado de cumplimiento de las obligaciones correspondientes dependerá de los recursos disponibles, pero esto no significa que tales tratados carezcan de fuerza jurídica, por cuanto se exime a los Estados del deber de satisfacer esos derechos tanto como sus recursos lo permitan y de asegurar un contenido mínimo en relación con ellos.

\section{La supuesta violación del principio de separación o división de los poderes}

La mayoría de las objeciones al control judicial de las omisiones legislativas, pueden reconducirse al supuesto desconocimiento del reparto constitucional de las funciones públicas que comporta.

Así, en relación con la previsión de una acción de inconstitucionalidad por omisión, se ha señalado que atentaría contra la libertad de configuración normativa o discrecionalidad del legislador, el cual debe conservar la facultad de determinar el momento en que ha de ser desarrollado un precepto constitucional. Ello alcanzaría especial importancia en el ámbito de las disposiciones relativas a los fines del Estado en materia económica o social, muy frecuentes en las constituciones contemporáneas, por cuanto el órgano legislativo sería el único idóneo para valorar las circunstancias imperantes en tales áreas y para decidir, en función de estas, la oportunidad de las 
leyes en desarrollo, según las prioridades trazadas y los recursos disponibles, y conforme a las necesidades de la población.

Incluso, se ha llegado a sostener que puede resultar conveniente reconocer al legislador la posibilidad de dejar en suspenso previsiones constitucionales poco realistas que hayan sido aprobadas en medio del fragor revolucionario o del utopismo que a menudo acompaña la labor de las asambleas constituyentes. En este sentido, se ha expresado:

Una alteración radical de la legalidad existente, producto de una acción de corte revolucionario, trae como consecuencia la aparición de un nuevo orden constitucional basado en principios antitéticos a los que regían con anterioridad. Las élites políticas de antaño caen y las sustituye una clase dirigente que responde y se mueve por pautas absolutamente enfrentadas a las anteriores. Los nuevos líderes pueden buscar, de manera consciente o inconsciente, la instauración de pretenciosos objetivos con los que alterar de forma sustancial todo el sistema anterior ya superado. Y fruto de estos fines políticos y de semejante programa de actuación quizá sea la instauración en la Carta Magna, con la que se intenta abrir la nueva época, de desmedidos encargos al legislador, dotados de una fuerte idea de obligatoriedad con el deseo de que no se frustre el ansia de construcción de la futura realidad, diseñada por contraste con la anterior.

En un supuesto así, el devenir de los acontecimientos puede templar la radicalidad inicial e imponer moderación ante el convencimiento de que se actuó por simple reflejo frente a lo anterior, y no por propia convicción de la bondad del nuevo programa constitucional. En este contexto nacido en la crítica constructiva a los extremismos del cambio revolucionario, esto es, de una racionalidad a posteriori frente a la irracionalidad inicial, pone en serios problemas la justificación de la omisión constitucional. ¿Resultaría adecuada una institución que obligase a realizar aquello que aún resta por hacer cuando ya no se aviene con las ideas dominantes? (Fernández, 2003, p. 43).

Por otro lado, ha suscitado cierto rechazo la posibilidad de que los órganos judiciales colmen lagunas jurídicas, derivadas de la falta de sanción de leyes necesarias para la plena efectividad de preceptos constitucionales. Ello implicaría una amenaza a las funciones propias del legislador y colocaría a los jueces en riesgo permanente de incurrir en usurpación de atribuciones. Especial reserva ha sido formulada, desde la perspectiva de un sistema concentrado de control de constitucionalidad erigido sobre la tradicional desconfianza hacia los órganos del Poder Judicial, en relación con la posibilidad de que los jueces ordinarios estén facultados, mediante el amparo constitucional, el control difuso de la constitucionalidad u otros medios procesales, para cumplir con esa tarea integradora.

Por último, se ha observado que el control judicial de las omisiones legislativas entraña un enorme peligro de politización de la jurisdicción constitucional, más aún cuando la omisión legislativa no es producto de una inadvertencia de legislador, sino una decisión deliberada. 
Las objeciones anteriormente señaladas, no resultan fundadas cuando se pretende negar la posibilidad o conveniencia de articular dicho control. Objeciones análogas se esgrimieron en su día contra el control judicial de constitucionalidad de las leyes, que han servido para subrayar las peculiaridades de este control y sus límites, no para negar su procedencia.

Sin embargo, la división de los poderes no puede ser concebida como la atribución, con carácter de exclusividad, de cada una de las principales funciones públicas a conjuntos orgánicos determinados, por cuanto son múltiples los supuestos de interrelación y de mutua justificación a ese principio reside en el necesario aseguramiento de un equilibrio entre los poderes, en resguardo de la libertad y de la democracia $^{20}$. En tal sentido, el establecimiento por la Constitución de un Tribunal o Corte Constitucional, u otra máxima instancia especializada en el control de constitucionalidad, implica por definición un condicionamiento externo de la acción del legislador, que no tiene de suyo nada criticable, pues con ello se garantiza la supremacía de la Constitución y de los derechos que consagra, sin perjuicio del abuso en que puede eventualmente incurrirse en el ejercicio de ese control.

De manera que, la aceptación de la fuerza normativa de la Constitución, hoy indiscutible, obliga a proteger la norma suprema de toda acción u omisión de los poderes públicos violatoria de sus disposiciones, sin que sea lícito reconocer al legislador un espacio de inmunidad al control judicial, cuando el desconocimiento de la Constitución se origina en su inactividad. Frente a lo que ha sido denominado expresamente como "agresión omisiva" (Bazán, 2003, p. 45) de la Constitución, el ordenamiento jurídico no puede mantenerse pasivo, sino que debe abrir caminos para la aplicación del control judicial de la constitucionalidad de la omisión legislativa $\mathrm{y}$, de manera general, para asegurar la vigencia de la Constitución ante el proceder omisivo de uno de los poderes constituidos.

El legislador no está facultado para disponer sobre la obra del poder constituyente, ni siquiera cuando esta pueda parecer en el futuro errado o inconveniente en sus consecuencias. Sin perjuicio de las posibilidades de adaptación de la Constitución a nuevas circunstancias, de la interpretación progresiva de sus preceptos e incluso de la mutación constitucional, la apelación al poder constituyente es la única vía válida para enmendar las disposiciones constitucionales que se estimen equivocadas, sin que sea lícito erigir al legislador en juez de la pertinencia y aplicabilidad de los preceptos constitucionales.

Además, en el ejercicio del control de constitucionalidad de las omisiones legislativas debe reconocerse al legislador un amplio margen de apreciación en la determinación de los recursos disponibles para el desarrollo de los preceptos constitucionales, así como para el establecimiento de las prioridades en materia económica y social y la fijación de la oportunidad de ese desarrollo legal, pero ello

20 También se ha reiterado esto en varios de los escritos del profesor Marcelino. 
no ha de conducir a negar la viabilidad y licitud de tal control en un Estado social y democrático de derecho.

La posibilidad de armonizar las exigencias de control de constitucionalidad de las omisiones legislativas, con el reparto constitucional de las funciones públicas se ha puesto de relieve en ordenamientos que poseen la acción específica y directa de inconstitucionalidad por omisión, como el derecho portugués, en que el Tribunal Constitucional ha reconocido al legislador cierta discrecionalidad en la determinación del momento en que debe ser dictada una regulación legal requerida por la Constitución "en lo tocante a una jerarquización y definición de prioridades de realización de los diversos fines estatales o de las diversas necesidades públicas.

A pesar de lo anterior, no puede aceptarse, que el legislador ostente libertad para determinar si desarrolla los preceptos constitucionales y en qué medida lo hace, cualquiera sea su tipo o naturaleza, pues todos son componentes de un conjunto jurídico de normatividad inobjetable frente al legislador y demás órganos del poder público.

\section{La supuesta vulneración del principio de legalidad y de la reserva legal}

En íntima conexión con la objeción antes reseñada, se aduce que una intervención judicial dirigida a colmar una omisión legislativa, representaría también un quebrantamiento del principio de legalidad y de la reserva legal, ya que los jueces no actuarían con sujeción a la ley sino, precisamente, en ausencia de ella, y establecerían, mediante sus sentencias, los criterios jurídicos aplicables en la materia carente de regulación legislativa, aun cuando ésta fuera de la expresa reserva legal. Según esta posición, claramente reseñada por Villaverde:

El principio de legalidad y la reserva de la ley emergen, pues, como expresiones de la posición del legislador como custodio de la Constitución y de las libertades individuales en ella garantizadas. De otra forma, si no pesara sobre la actuación de la Administración y de los Tribunales la presunción iure et de iure de la constitucionalidad de la ley, se atribuirán, por la eficacia directa de la Constitución, o la de colmar las lagunas legislativas, interpretando y deduciendo por sí mismos reglas de derecho para el caso concreto que deban atender. Reglas que pueden alcanzar una eficacia similar a la de la ley si emanan de las sentencias de los Tribunales superiores, cuya función es la de unificar la doctrina jurisprudencial, o de normas reglamentarias de eficacia general. Si esto fuere así, se vaciaría de contenido el principio de legalidad y se vulneraría la reserva de la ley al ser sustituido el legislador por los otros Poderes del Estado, cuando el sentido de ambos principios es el de asegurar el carácter insustituible de la ley como mediadora entre la Constitución y el Estado y la Sociedad, y su función concretadora de las normas constitucionales en el seno del ordenamiento jurídico (1977, p. 125). 
Es importante apuntar que tal advertencia doctrinal descansa, en algunos aspectos, sobre una concepción de las relaciones entre los jueces y la legislación, propia de los sistemas de control concentrado de la constitucionalidad, particularmente en lo que atañe al alcance que se atribuye a la presunción de constitucionalidad de la ley, que eximiría a esta del control de los jueces ordinarios, solo facultades para plantear la cuestión de inconstitucionalidad si estiman que la ley en principio aplicable al caso es contrario a la Constitución.

Pero, la objeción tiene una significación más general cuando se refiere a la tarea integradora que los jueces podrían desempeñar ante las omisiones legislativas, pues la existencia en un ordenamiento de un sistema de control difuso (o mixto) de la constitucionalidad, no excluye la vigencia del principio democrático y del Estado de Derecho, en virtud de los cuales el órgano legislativo, como instancia deliberante y representativa, políticamente responsable, debe adoptar las decisiones jurídicaspolíticas de mayor trascendencia, las cuales, al quedar plasmadas en leyes, trazan el marco dentro del cual los Tribunales han de cumplir la función jurisdiccional. Ello cobra especial importancia cuando se trata de las materias cuya regulación está constitucionalmente reservada al Parlamento.

Sin embargo, el principio de legalidad y la reserva legal no deben ser entendidos como un obstáculo a la labor de interpretación e integración del Derecho que los jueces están llamados a cumplir cotidianamente. El Estado de Derecho presupone la existencia de un poder judicial, capaz de administrar justicia con independencia y tutelar de manera efectiva los derechos constitucionales reconocidos, lo cual con frecuencia exigirá atemperar el texto de las disposiciones legales, en vista de particularidades del caso, o reinterpretarlo a la luz de la Constitución, como también acudir a preceptos que regulen situaciones similares o a los principios generales del derecho. Nada de esto choca con los principios señalados.

Pero la labor integradora desempeñada por los jueces ante las omisiones legislativas puede ir más allá, es preciso observarlo, de las facultades indicadas, que hoy son consustanciales a la función judicial. Este plus estriba en que, ante la falta de regulación legislativa en una materia que constitucionalmente la requiere, el juez, a partir de los datos que le ofrece el ordenamiento constitucional y legal, pero sin que aquél predetermine una única solución como válida, procedería a cubrir la omisión legislativa para dotar de eficacia el precepto constitucional, con efectos en principio limitados al caso concreto pero que se generalizarían en virtud de reglas jurídicas que puedan entrar en juego, como la del precedente o la que establece, en nuestro derecho, el carácter vinculante de las interpretaciones sentadas por la Sala Constitucional.

Es aquí donde debe situarse el quid de la cuestión; no en la posibilidad de que los jueces integren lagunas de la ley, ante la necesidad de resolver un caso no previsto expresamente en ella, pero que está comprendido por su programa normativo, lo cual está fuera de discusión, sino en la facultad de los tribunales para colmar una laguna de la legislación -que de acuerdo con la Constitución no debería existir-, ante la 
necesidad de resolver un caso respecto del cual la Constitución solo establece algunos parámetros de solución, sin descender a todos los detalles, cuya determinación ha sido encomendada al legislador.

\section{El abandono del supuesto axioma de la jurisdicción constitucional como legislador negativo}

Con frecuencia se aduce, para fundamentar el rechazo a ciertas modalidades de control de la constitucionalidad de las omisiones legislativas, que los tribunales constitucionales deben mantenerse dentro del ámbito de su función específica, lo cual consistiría, guardando fidelidad con el pensamiento de Kelsen, en actuar como un legislador negativo.

Es sobradamente conocida la caracterización kelseniana de los tribunales constitucionales como legisladores negativos, conforme a la cual la anulación de una ley como consecuencia necesaria de la declaratoria de su inconstitucionalidad sería una manifestación, e incluso un ejercicio, de poder legislativo; estaría reservada la creación de la ley, mientras que el Tribunal Constitucional participaría de la función legislativa negativamente, al anular las leyes que declare contrarias a la Constitución.

Los postulados sobre los que se asienta el control de la constitucionalidad de las leyes, como lo son la garantía de la supremacía de la Constitución y de su fuerza normativa, y los principios que le imponen limitaciones, como la división de los poderes y el principio democrático, no exigen que los jueces o Tribunales Constitucionales actúen solo negativamente, con pronunciamientos de efectos ablativos o supresores sobre la ley. Lo que reclaman es la protección de la Constitución frente a las acciones $\mathrm{u}$ omisiones legislativas, mediante instrumentos procesales que han de ejercerse sin usurpar la potestad legislativa, lo cual no necesariamente ha de lograrse, una vez que la inconstitucionalidad ha sido constatada, por medio de una sentencia anulatoria. La respuesta anulatoria puede en ocasiones resultar más dañina, desde la óptica de los bienes constitucionales involucrados y del principio de división de los poderes, que la supervivencia de la ley cuestionada hasta la intervención del legislador, en los términos y plazos que el propio fallo puede establecer; en otros casos, la anulación resulta simplemente imposible, como ocurre cuando nos hallamos ante una omisión absoluta del legislador.

Por estas y otras razones que no sería pertinente abordar aquí, las cortes o tribunales constitucionales, europeos y latinoamericanos, acuden, cada vez con más frecuencia, a tipos de sentencia que difieren de la completa desestimación de la inconstitucionalidad y de la anulación inmediata del precepto, tales como las sentencias interpretativas, que determinan la significación que debe atribuirse al precepto para excluir la inconstitucionalidad o que desechan una interpretación del precepto considerada contraria a la Constitución; las de nulidad parcial cualitativa (para algunos una modalidad de las anteriores), que sustraen del ámbito de aplicación de un precepto, sin alterar su texto, situaciones que podían estimarse incluidas en 
él; las que difieren los efectos anulatorios; las aditivas, llamadas así por la doctrina italiana porque extienden el alcance de un precepto a supuestos no comprendidos en el enunciado legal; y las de incompatibilidad con la Constitución o meramente declarativas de la inconstitucionalidad de la norma legal, desprovistas de efectos anulatorios, a menudo acompañadas de recomendaciones o exhortaciones dirigidas al legislador.

La jurisdicción constitucional, si quiere seguir siéndolo, no puede asumir la posición del legislador en el proceso de creación del derecho. No es legislador ni negativa ni positivamente, pues cuando anula un precepto legal lo hace porque la preservación de la supremacía de la Constitución impone la exclusión de una ley incompatible con sus disposiciones, y cuando acude a otras modalidades de sentencias lo hace por entender que son un medio más efectivo y razonable para proteger la Constitución globalmente considerada, no porque pretenda establecer la regulación jurídica que le parezca más conveniente en una determinada materia.

Tanto en el primero como en el segundo caso, la intervención de la jurisdicción constitucional puede tener una incidencia positiva sobre el legislador, por cuanto la anulación de un precepto legal frecuentemente motiva la aprobación de un precepto sustitutorio, conforme con la Constitución, elaborado teniendo en cuenta los fundamentos de la sentencia correspondiente. En ambos casos, por otro lado, puede resultar alterada la distribución constitucional de las funciones públicas, ya que la libertad de configuración normativa o libertad política del legislador se ve menoscabada por todo pronunciamiento que abandone los parámetros jurídicos que el Derecho Constitucional ofrece y se centre en valoraciones de oportunidad o conveniencia, o que produzca un efecto normativo no querido por el legislador ni exigido por la Constitución, sin que sea relevante la forma expresiva, positiva o negativa, empleada en la sentencia.

Además, no se pretende negar la carga política que suele ir adosada a los fallos constitucionales. Pero ello, no debe conducir a desconocer la especificidad de la labor jurisdiccional cumplida por las Cortes o Tribunales Constitucionales u órganos similares, los cuales han de resolver las cuestiones planteadas dentro de los linderos de la interpretación constitucional y del derecho que le sirve de base, sin perjuicio de los ingredientes políticos que pueden entrar en juego.

Por ejemplo, cuando a fines de los años sesenta el Tribunal Constitucional Federal de Alemania asumió francamente el tema de la inconstitucionalidad por omisión en la producción de normas generales, alertó que los jueces, para remediarla, debían tener en cuenta tanto un claro mensaje constitucional incumplido, como el trascurso de un tiempo ya irrazonable sin que se lo obedeciera, y, por último, la posibilidad de que el Poder Judicial pudiese cubrir material y jurídicamente el vacío, prescindiendo del legislador.

Tales directrices conservan hoy vigencia. De modo que no es tarea simple atender jurisdiccionalmente la cobertura de esa inconstitucionalidad por omisión. Supóngase que la constitución encomienda al Poder Legislativo establecer un régimen de 
participación de los trabajadores en las ganancias de las empresas, con la colaboración en su dirección y en el control de la producción, y que el Congreso permanezca renuente en esa obligación. Una magistratura constitucional que decidiese aquí poner punto final a la mora legislativa, tendría frente a sí un trabajo potente para elaborar soluciones individuales, y más todavía para redactar una norma general subsidiaria, en un asunto de por sí opinable y harto controvertido, con múltiples y distintas fórmulas de instrumentación, donde entran en juego diferentes índices de rentabilidad, según las actividades y el tipo de establecimiento considerados, opuestos criterios políticos de redistribución de la riqueza, mediciones y resultados diversas acerca del impacto económico de las posibles cuotas y modos de repartir, entre otros.

Así pues, una breve sinopsis histórica muestra que la jurisdicción constitucional no fue concebida inicialmente para reparar la inconstitucionalidad por omisión, sino solamente para inaplicar reglas inconstitucionales, en el caso concreto ("Marbury vs. Madison"). Que después, bajo las directrices de Hans Kelsen, pudo operar como legislador negativo, derogando las normas inconstitucionales. Y que más tarde, adoptó papeles de legislador positivo, impulsando la sanción de nuevas normas, v.gr. mediante las sentencias exhortativas. Finalmente, en una cuarta etapa, al atender la inconstitucionalidad por omisión en la producción de normas generales, cubrió vacíos lagunosos para el caso concreto, e impulsó la sanción de las normas ausentes, instando la actividad nomogenética del legislador ocioso, pautándole incluso ciertas directrices de contenido en la emisión de tales normas, y estableciendo reparaciones para el afectado por la mora legislativa genética.

El fin de esta cuarta etapa parece alcanzar, según las soluciones de Chiapas y de Ecuador, una quinta alternativa: la gestión de un tribunal constitucional como legislador suplente y precario, sancionado bajo condición resolutoria la norma general ausente (esto es, hasta que quien debía elaborarla, lo haga efectivamente).

Si bien cabe destacar el ánimo de justicia y de ejecución real de la constitución que caracteriza a esta última posibilidad, en aras de otorgarle genuina eficacia y positiva vigencia de los derechos personales; y que la novedosa reprogramación que importa de la doctrina clásica de división de poderes no la descalifica de por sí in limine, la problemática técnica, política y funcional que conlleva, y que hemos detallado anteriormente, no aconseja proyectarla como una solución deseable para todo sistema constitucional. Antes, lo mejor será evaluar con cautela las experiencias que ocurren en los Estados que la han adoptado, antes que repetirla ya en otros. Para aquellos, ciertamente, importa un desafío digno de una cuidadosa observación por parte del resto del derecho comparado (Fernández, 1998).

Para el caso ecuatoriano, cabe alertar por último que la propia Constitución deja en parte la instrumentación de la aptitud legisferante de su Corte Constitucional21. Ello, deja abierta la posibilidad de enmarcar tal competencia dentro de ciertos

21 Art. 436, inciso 10 (parágrafo 1 ). 
parámetros, como los enunciados por el Tribunal Constitucional federal alemán, en torno a la factibilidad, en un caso concreto, de ejercer tal función prescindiendo absolutamente del legislador.

\section{LA OMISIÓN LEGISLATIVA CONVENCIONAL}

Para comenzar con este segmento del texto, haremos referencia al control de convencionalidad (en adelante CCV), que en palabras de (Sagüés, 2011) se define como el control que usualmente ha realizado la Corte Interamericana de Derechos Humanos cuando ha juzgado las violaciones a la Convención por parte de Estados y ha ordenado a los mismos realizar correcciones de la inconvencionalidad, modificando la legislación para adecuar los preceptos legales a lo establecido en la Convención, habiendo casos de órdenes de naturaleza constitucionales. Así mismo, La Corte IDH ha señalado en un fallo reciente que la inexistencia de un recurso efectivo contra las violaciones a los derechos reconocidos por la Convención constituye una transgresión de esta por el Estado Parte en el cual semejante situación tenga lugar (Cubides, 2013).

De manera que, a partir del control de convencionalidad, es posible obligar a los Estados a que adopten diversas medidas legislativas en situaciones específicas ${ }^{22}$. A partir de allí, podemos comenzar a hablar de una omisión legislativa convencional, que se presenta cuando los Estados no toman en cuenta los fallos de la Corte IDH ${ }^{23}$ y continúan violando los derechos humanos. Seguidamente ilustraremos algunos casos en los que se podría presentar esta novedosa figura jurídica ${ }^{24}$ :

Antes de ello, cabe destacar que en la República Bolivariana de Venezuela no existe una protección efectiva a los derechos de los ciudadanos, puesto que debido al régimen imperante en la actualidad, se evidencia la represión estatal. Como lo

22 Al respecto, es importante considerar que "el control difuso de convencionalidad resulta ser un mecanismo complementario, pues cada uno de los países que ha suscrito la CADH posee medios para regular qué leyes, reglamentos, decretos y demás actos con relevancia en el mundo del derecho puedan llegar a afectar los derechos humanos de cualquier persona, para que se ajusten al texto constitucional consagrado como norma de normas y que debe por lo tanto ser respetado" (Cubides, Sánchez, \& Pérez, 2013).

23 Ello, porque se debe tener en cuenta la "importancia de las sentencias de la Corte IDH, como parámetros para tribunales homólogos, y el uso del control de convencionalidad por los tribunales constitucionales son considerados caminos sugeridos como vías para el logro de una implementación efectiva de las decisiones del SIDH", como lo afirman (Cubides \& Vivas, 2012).

24 La Corte IDH se ha pronunciado en diversas sentencias respecto a la omisión legislativa: Corte IDH. Caso Almonacid Arellano y otros vs. Chile. [Ante la falla legislativa de no adoptar leyes contrarias a la CADH; el Judicial permanece vinculado, al deber de garantía. Todo Estado es responsable por omisiones de sus órganos en violación de derechos, en violación de derechos internacionalmente consagrados. Todo Estado es responsable por omisiones de sus poderes]. Corte IDH. Caso Herrera Ulloa vs. Costa Rica. Excepciones Preliminares, Fondo, Reparaciones y Costas. Sentencia de 2 de julio de 2004. Serie C No. 107, párrafo 126 [acciones del Estado deben estar sujetas a un escrutinio riguroso. En un sistema democrático; las omisiones, por parte de las autoridades legislativas. El actuar del Estado está sujeto al escrutinio por parte de las, acciones del Estado están sujetas también al escrutinio por parte de la opinión pública]. 
afirma (Meier, 2013) este país ha intentado sustraerse del control internacional del SIDH, denunciando la CADH.

A su vez, Venezuela hace un control de constitucionalidad ilegítimo a los fallos de la Corte IDH, con el fin de inaplicarlos en el ordenamiento jurídico interno y continuar con el desconocimiento de los Derechos Humanos. Un ejemplo de ello, lo muestra (Brewer Carías, 2011, p. 577) frente al caso de Leopoldo López, afirmando que la Sala Constitucional del Tribunal Supremo de Venezuela, sometió a control de constitucionalidad el fallo de la Corte IDH, con el fin de desconocer la legitimidad de la Corte.

Asimismo, en el caso Leopoldo López vs. Venezuela, la Corte IDH condenó al Estado venezolano ${ }^{25}$ por violación del derecho político al sufragio pasivo del señor López. En respuesta a ello, el Estado consideró que la sentencia era inejecutable a través de una "acción innominada de control de constitucionalidad" (Brewer Carías, 2011, p. 579). De manera que, Venezuela busca tener poder por encima de cualquier normatividad nacional e internacional.

No obstante, es importante considerar que la Constitución Política de este país en su artículo 31 establece que "es obligación del Estado adoptar las medidas necesarias para dar cumplimiento a las decisiones adoptadas por órganos internacionales de protección de los Derechos Humanos" (Constitución Política de Venezuela, 1999), por ello, se puede afirmar que el Estado incumple la normatividad constitucional y desconoce los pactos internacionales, a su vez, ninguno de los órganos estatales se encarga de velar por el cumplimiento de lo establecido en la Carta Política, por ello se evidencia la inconstitucionalidad por omisión legislativa.

A su vez, la Corte IDH ha condenado a los Estados latinoamericanos a adoptar medidas legislativas, que aseguren la protección efectiva de los derechos humanos, si no se adoptan por los Estados, como es el caso venezolano, estaríamos ante omisiones legislativas convencionales ${ }^{26}$.

25 Otros casos del Estado venezolano: Corte IDH. Caso Apitz Barbera y otros (Corte Primera de lo Contencioso Administrativo) vs. Venezuela. Excepción Preliminar, Fondo, Reparaciones y Costas. Sentencia de 5 de agosto de 2008. Serie C No. 182, párrafo 253[ la "inconstitucionalidad por omisión legislativa de la Asamblea Nacional [...] con motivo del procedimiento, legislativo iniciado para sancionar el denominado Proyecto de Código de Ética y Disciplina, del Juez Venezolano o Jueza Venezolana, elaborado por dicha instancia legislativa en el año 2003]. Corte IDH. Caso Castillo González y otros Vs. Venezuela. Fondo. Sentencia de 27 de noviembre de 2012, párrafo 110 [internacionalmente responsable por actos $\mathrm{u}$ omisiones que menoscaben los derechos humanos reconocidos, ilícito del Estado cuando un comportamiento consistente en una acción u omisión: a) Es, comportamiento de todo órgano del Estado, ya sea que ejerza funciones legislativas, ejecutivas, judiciales].

26 Corte IDH. Caso de la "Panel Blanca" (Paniagua Morales y otros) vs. Guatemala. Reparaciones y Costas. Sentencia de 25 de mayo de 2001. Serie C No. 76, párrafo 203. [Debe adoptar "las medidas legislativas o de otro carácter que fueran necesarias para hacer efectiva la CADH"] (Corte IDH, 2001). Corte IDH. Caso de la Comunidad Mayagna (Sumo) Awas Tingni vs. Nicaragua. Fondo, Reparaciones y Costas. Sentencia de 31 de agosto de 2001. Serie C No. 79, párrafo 138. [Deber de adoptar medidas legislativas para la demarcación de propiedad indígena, legislativas para la demarcación de propiedad indígena acorde con sus valores, Deber de adoptar medidas, legislativas 


\section{A MODO DE REFLEXIÓN}

Para finalizar, esperamos haber puesto de relieve la significación de las cuestiones jurídicas envueltas en el control de constitucionalidad de las omisiones legislativas, y la variedad de reacciones defensivas del organismo constitucional (Poder Judicial) ante las vulneraciones o amenazas a sus preceptos derivadas no de la acción de la inactividad del legislador.

El estudio de la materia indica que la articulación de un sistema eficiente de protección de la Constitución ante las omisiones legislativas, que a la vez sea respetuoso del reparto constitucional de las funciones públicas y del principio democrático, exige de los jueces firmeza en el aseguramiento de la fuerza normativa de la Constitución, así como conciencia de los límites de sus poderes y una prudente aplicación de estos. Del lado del legislador, es necesaria una cierta diligencia en el cumplimiento de sus tareas legislativas, y el acatamiento de la intimación a legislar que provenga de los órganos constitucionales (Corte o Tribunales Constitucionales) facultados para ello, pues ante una situación generalizada de pasividad del legislador se corre el riesgo bien de restar virtualidad jurídica a la acción de inconstitucionalidad por omisión, bien de propiciar un deslizamiento de las instancias judiciales hacia espacios extraños al ámbito natural de ejercicio de sus competencias.

Frente a ciertos sectores políticos que son muy poco proclives a la figura, la doctrina defiende su mantenimiento, "no para deslegitimar gobiernos y asambleas inertes, sino para asegurar una vía de publicidad crítica y procesal contra la Constitución no cumplida" (Bazán, 2003, p. 105).

El instituto, en definitiva, desborda interés y reclama un tratamiento serio y riguroso acorde con sus repercusiones y potencialidades en la circunstancia del imperio del Estado de Derecho. Esperamos que la visión del tema en el Derecho Comparado haya servido para despertar el interés de la conciencia jurídica del lector y le haya hecho reflexionar un tanto sobre las deficiencias y las tareas de nuestro actual sistema, basado en un Estado Social y Democrático de Derecho que presenta importantes

para la demarcación de propiedad indígena acorde con sus usos]. Corte IDH. Caso Comunidad Indígena Yakye Axa vs. Paraguay. Fondo Reparaciones y Costas. Sentencia 17 de junio de 2005. Serie C No. 125, párrafo 225. [Deber de adoptar en plazo razonable medidas legislativas para reclamación de tierra que, razonable medidas legislativas que creen mecanismo eficaz de reclamación de tierras, Deber estatal de adoptar, indígenas, Deber de adoptar en plazo razonable medidas legislativas para reclamación de tierra que retomen]. Corte IDH. Caso Claude Reyes y otros vs. Chile. Fondo, Reparaciones y Costas. Sentencia de 19 de septiembre de 2006. Serie C No. 151, Párrafo 102. [Incumplimiento del art. 2 por no adoptar medidas legislativas para garantizar la libertad, de pensamiento, Incumplimiento del art. 2 por no adoptar medidas legislativas para garantizar la libertad, Medidas legislativas]. Corte IDH. Caso del Pueblo Saramaka. vs. Suriname. Excepciones Preliminares, Fondo, Reparaciones y Costas. Sentencia de 28 de noviembre de 2007. Serie C No. 172, Párrafo 175. [Derecho a la Propiedad Privada, Obligación de adoptar medidas legislativas para respetar el libre, ejercicio de la protección judicial, Obligación de adoptar medidas legislativas para asegurar ejercicio sin, de otra índole para el respeto del libre ejercicio de la protección judicial, Medidas legislativas]. 
avances pero al que todavía le falta una auténtica y enraizada consolidación. No debemos conformarnos con lo ya conseguido y aletargarnos ante unos mecanismos que aún no satisfacen las elevadas exigencias de nuestra evolucionada época. Y ello no puede ser de otro modo porque "sólo merece la libertad y la vida el que cada día sabe conquistarlas" (Von Ihering, 1985, p. 136).

¡Esta tesis no supone verdad, es tan solo nuestro punto de vista. Sea bienvenido el debate!

\section{REFERENCIAS}

Bazán, V. (s.f.). Hacia la plena exigibilidad de los preceptos constitucionales: el control de las omisiones inconstitucionales.

Bazán, V. (s.f.). Respuestas normativas y jurisdiccionales frente a las omisiones inconstitucionales: una visión de derecho comparado, recuperado de: http:// bibliohistorico.juridicas.unam.mx/libros/2/544/5.pdf

Bazán, V. (2007). Algunos problemas y desafíos actuales de la jurisdicción constitucional e Iberoamérica. Recuperado de: www.jurídicas.unam.mx.

Bidart, G. (1995). Algunas reflexiones sobre las omisiones constitucionales. En V. Bazán, La inconstitucionalidad por omisión. Bogotá: Temis.

Bidart, G. (1995). El derecho de la Constitución y su fuerza normativa. Buenos Aires: Ediar.

Brewer Carías, (2011). El ilegítimo «control de constitucionalidad» de las sentencias de la corte interamericana de derechos humanos por parte de la sala constitucional del tribunal supremo de justicia de venezuela: el caso Leopoldo López vs. Venezuela, septiembre 2011. Anuario Iberoamericano de Justicia Constitucional, núm. 16, Madrid .

Caballenas, G. (1988). Diccionario jurídico elemental . Buenos Aires: Heliasta.

Cabanellas, G. (s.f.). Diccionario de derecho usual. Buenos Aires: Bibliográfica Omega.

Capitant, H. (1986). Vocabulario jurídico. Buenos Aires: Depalma.

Cubides, J. A. (2013). El origen del control de convencionalidad (CCV) y sus implicaciones para los Estados que reconocen el Sistema Interamericano de Derechos Humanos (SIDH). Ambiente Jurídico, 105-121.

Cubides, J. A., Sánchez, M. L., \& Pérez, C. P. (2013). El nuevo control difuso de convencionalidad como mecanismo para la protección de los derechos humanos. Rostros y Rastros, 46-54.

Cubides, J. A., \& Vivas, T. G. (2012). Diálogo judicial transnacional en la implementación de las sentencias de la Corte Interamericana. Entramado, 184200.

Da Silva, J. (1992). Curso de Direito Constitucional Positivo. San Pablo: Malheiros. Díaz de León, M. A. (1986). Diccionario de derecho procesal penal. Porrúa. 
Eto, G. (marzo de 2015). La inconstitucionalidad por omisión en su vertiente jurisprudencial y la inconvencionalidad por omisión: algunas reflexiones y los antídotos para enfrentar esos males contemporáneos. Ciudad de México, México.

Fernández, J. (1998). La inconstitucionalidad por omisión. Madrid: Civitas.

Fernández, J. (2003). Aproximación al concepto de inconstitucionalidad por omisión. En M. Carbonell. En busca de las normas ausentes. Ensayos sobre la inconstitucionalidad por omisión. UNAM.

Fernández, J. (2003). La omisión legislativa en la Constitución del Estado de Veracruz. En Derecho procesal constitucional (4a ${ }^{\mathrm{a}}$ ed.). México: Porrúa.

Gómez, J. J. (1993). Direito Constitucional. Coimbra.

Hernández, L. (2000). La acción de inconstitucionalidad por omisión legislativa en la Constitución mexicana. Un avance en el acceso a la justicia constitucional. Biblioteca Jurídica virtual. Instituto de Investigaciones Jurídicas UNAM.

Instituto de Investigaciones Jurídicas UNAM. (2001). Enciclopedia jurídica Omeba. Buenos Aires: Bibliográfica Argentina.

Jiménez, J. (1998). La declaración de inconstitucionalidad de una ley. En F. Rubio, \& J. Jiménez. Estudios sobre jurisdicción constitucional (p. 125). Madrid: Mc Graw Hill.

Kelsen, H. (1979). Teoría general del derecho y del Estado. UNAM.

Kelsen, H. (1988). Escritos sobre la democracia y el socialismo. "La garantía jurisdiccional de la Constitución (la justicia constitucional)”. (J. M. Manero, Trad.) Madrid.

Larenz, K. (2003). Metodología de la ciencia del Derecho. Barcelona: 1944.

Lorenzetti, R. (setiembre, 2007). Revista Argentina de Teoría Jurídica, vol. 10. Universidad Torcuato di Tella.

Meier, E. (2013). La 'desconstitucionalización' del derecho internacional, de los derechos humanos en Venezuela. En C. d. constitucionales, Anuario iberoamericano de justicia constitucional (pp. 187-230). Madrid. ACLARAR

Muñoz, H. A., \& Prieto, E. (1996). Elementos de técnica legislativa. San José de Costa Rica. San José de Costa Rica: Prodel.

Osorio, M. (1992). Diccionario de ciencias jurídicas y sociales. Buenos Aires: Heliasta.

Pina, R. (1991). Diccionario de Derecho. México D.F.: Porrúa.

Racimo, F. (2006). Democracia deliberativa. Buenos Aires: Ad-Hoc.

Real Academia de Lengua Española. (2001). Madrid, España: RAE.

Rubio, F. (1993). La forma de poder, estudios sobre la Constitución. Madrid.

Sagues, N. (1998). La interpretación judicial de la Constitución. Buenos Aires: Depalma. 
Sagues, N. (2002). Instrumentos de la justicia constitucional frente a la inconstitucionalidad por omisión. En U. I. Jurídicas. Instrumentos de tutela y justicia constitucional. Memoria del VII Congreso Iberoamericano de Derecho Constitucional (p. 617). México DF: Universidad Nacional Autónoma de México.

Sagües, N. (2009). Novedades sobre inconstitucionalidad por omisión: la Corte Constitucional de Ecuador como legislador suplente y precario. Estudios Constitucionales.

Sagües, N. (s.f.). La acción de inconstitucionalidad por omisión en la provincia de Río Negro. En V. Bazán. COMPLETAR

Sagüés, V. N. (2011). El control de convencionalidad. En particular sobre las Constituciones.

Silva, J. (2003). Aplicabilidad de las normas constitucionales. UNAM.

Villaverde, I. (1977). La inconstitucionalidad por omisión. Madrid: Mc Graw Hill.

Von Ihering, R. (1985). La lucha por el derecho. Madrid: Civitas.

Zagrebelski, G. (2005). La Constitución y sus normas. Teoría de la Constitución. México DF: Porrúa. 